\title{
The Unwinding of Cross-shareholding in J apan: Causes, Effects, and Implications
}

\author{
Hideaki Miyajima \\ (Waseda University, Harvard University, and RIETI) \\ and \\ Fumiaki Kuroki \\ (NLI Research Institute)
}

May 2006

This paper was prepared for a chapter of the book, Corporate Governance in J apan: Institutional Change and Organizational Diversity, edited by Masahiko Aoki, Gregory J ackson, and Hideaki Miyajima. Keisuke Nitta and Nao Saito helped us to construct the data on which it is based. Yurie Otsu provided us with excellent assistance. An early draft was presented at RIETI, Hitotsubashi University, the Association for Financial Studies, and Tokei-kenkyu-kai. Comments from Naoto Abe, Katsuyuki Kubo, Takeo Hoshi, Yasuhiro Yanagawa, and Kazumi Asako, and Hiroshi Osano were extremely helpful.

Correspondent address: miyajima@fas.harvard.edu 


\begin{abstract}
Considering that the ownership structure of J apanese corporations has changed dramatically in the 1990s, this paper address a series of questions related to these changes: Why is cross-shareholding, which has been in place for almost three decades, now beginning to unwind (and what are the mechanisms of the unwinding)? What explains the increasing diversity in the patterns of cross-shareholding among J apanese firms? Lastly, what are the implications of the changing ownership structure on firm performance? Using detailed and comprehensive data on ownership structure including individual cross-shareholding relationships and other variables (Tobin's q) developed by Nissai Life Insurance Research Institute and Waseda University, we highlight the determinants of the choice between holding or selling shares for both banks and firms. We show that profitable firms with easy access to capital markets and high foreign ownership prior to the banking crisis have tended to unwind cross-shareholdings, while low-profit firms with difficulty accessing capital markets and low foreign ownership in the early 1990s have tended to keep their cross-shareholding relationships with banks. We also show that high intuitional shareholding and, somewhat surprisingly, block shareholding by corporations have positive effects on firm performance, while bank ownership has had a consistently negative effect on firm performance since the mid-1980s. We use these findings to address some policy implications and to provide some perspectives on the future of the ownership structure of Japanese firms.
\end{abstract}

J EL classification; G21; G32; K22; L 25

Key words: Ownership structure; cross shareholding, main bank relationship, firm performance; Banks' Shareholding Restriction Law 


\section{Introduction}

The ownership structure of Japanese firms used to have the following characteristics: shares were highly dispersed, managers and foreigners owned only limited stakes in companies, and substantial blocks of shares were held by corporations and financial institutions. Cross-shareholding, or intercorporate shareholding between banks and corporations, and among corporations, was extensive, and played an in important role in distinguishing, at least until the early 1990s, Japan's ownership structure from that of other countries. Evolving from the postwar economic reforms, Japan's unique ownership structure had become well established by the late 1960s, mainly because top managers considered it to be effective in warding off hostile takeover threats. The remarkable stability of this ownership structure may explain why it lasted for almost three decades.

Cross-shareholding has also played a key role in supporting Japanese management and growth-oriented firm behavior in the postwar period (e.g. Abegglen and Stalk 1985, Porter 1992, 1994). It encouraged the patterns of stable shareholding that have allowed managers to choose growth rates that deviated from the stock price maximization path (Odagiri 1992) and to adopt steady dividend policies that were insensitive to profit (with important implications for governance). Furthermore, the joint ownership of debt and equity by banks purportedly enhanced corporate performance by improving their monitoring of client firms and helping to mitigate asset substitution problems. The high level of ownership by non-financial institutions has also had a significant influence on the monitoring of Japanese companies (Sheard 1994, Yafeh and Yosha 2003).

The ownership structure that took root during the postwar period has undergone dramatic changes over the past decade, however. Foreign investors began to increase their stakes in Japanese companies in the early 1990s, especially in larger firms. And more recently, the ratio of shares held by stable shareholders (antei kabunushi) began to plummet from previous heights. Table 1 shows the stable shareholder ratio for the period from 1987 to 2002 (estimated by NLI (Nippon Life Insurance) Research Institute; henceforth, NLIR). The stable shareholder ratio is defined as the ratio of shares held by commercial banks, insurance companies, and non-financial firms (business partners and the parent company) to total shares issued by listed firms, calculated on a value basis (market valuation on the reference date). Until the 1990s, stable shareholders were assumed to be 
friendly insiders. The stable shareholder ratio has been declining since the mid-1990s, and the rate of decline has accelerated since 1999 . The ratio was $45 \%$ in the early 1990 s but plunged to only $27.1 \%$ in 2002. The last three columns of Table 1 show the shares owned by the three categories of investors categorized as stable shareholders -- banks, insurance companies, and non-financial firms. While cross-shareholding between corporations decreased only slightly, ownership of corporate shares by financial institutions, and banks in particular, dropped significantly.

It is important to note that the changes to the ownership structure of Japanese firms that occurred in the 1990s were accompanied by growing diversity of ownership. According to Table 2, the degree of dispersion of ownership rose as foreigners and individuals boosted their stake in Japanese corporations. Although the average ratio of shares held by financial institutions decreased $5 \%$ points during this decade, the standard deviation of this ratio increased. As the ownership structure of Japanese companies has become increasingly differentiated and diversified, stable shareholdings have unwound.

\section{$==$ Table $1 / 2$ about here $===$}

The dramatic changes mentioned above naturally give rise to a series of questions: Why is foreign shareholding in Japanese firms on an increasing trend? Why did cross-shareholding, which had been fairly constant for more than thirty years, begin to dissolve in the mid-1990s? If cross-shareholding had been a response to a rising takeover threat, then why did this practice begin to decline just as the takeover threat grew much more serious than it had been in the 1980s? Given the increasing variance in the cross-shareholding ratio among firms, what attributes of firms determine the extent of their cross-shareholding? And lastly, what are the welfare implications of the changing ownership structure for firm performance? The task of this chapter is to answer these questions, using detailed and comprehensive data on ownership structure and individual cross-shareholding relationships developed by NLIR and Waseda University.

To determine why foreigners are increasing their stakes in Japanese firms, we conduct a brief test of the home bias hypothesis, which predicts that such investors tend to purchase large and well-established stocks (Kang and Stultz 1997, Murase 2001). Using simple estimation, we present evidence that foreigners increased investments not only in large firms with high bond dependency, but also in growing firms with low default risk.

Next, to shed light on the primary concern of this chapter -- the causes of the unwinding of 
cross-shareholding, we approach the choice to sell from two sides, looking at the choice made by corporations to sell their bank shares, and by banks to sell their corporation shares. For the former, we estimate a Logit model in which a corporation's decision to sell off bank shares is regressed on its need to sell, the financial health of the bank, pressure from capital markets on the corporation, the takeover threat, and the corporation's relationship to the bank. From this estimation, we found that profitable firms with easy access to capital markets and high levels of foreign ownership prior to the banking crisis tended to wind down cross-shareholding, while low-profitability firms with difficulty accessing capital markets and low levels of foreign ownership in the early 1990s tended to maintain cross-shareholding arrangements with their banks.

Our second Logit model regresses the bank's choice to sell corporate shares on the bank's portfolio factors, the bank's need to sell, market pressure on the bank, growth potential, the risk level of the corporate investment, and the strength of the bank's relationships with those corporations. Consequently, we found that a bank's decision to sell off a stock is determined not only by portfolio factors, but also by its long-term relationships with firms. After the banking crisis, and particularly after 1999, banks reduced shareholding mainly by selling shares with higher liquidity and higher expected rates of return (i.e. shares which were easy to sell), while holding onto shares of firms with which they had long-term relationships. This was especially true when a main-bank relationship existed. Thus, the investment behavior of banks was shaped by a perverse incentive that not only undermined corporate governance but also led to the degrading of their own portfolios.

Lastly, we estimate a standard model to measure the effects of firms' cross-shareholding and other shareholding patterns on corporate performance. The conjectures that are tested in this estimation support the view that stresses the costs rather than the benefits of the Japanese ownership structure. Cross-shareholding may reduce the pressure from stock markets but also may encourage managerial entrenchment and diminish rather than enhance performance by allowing managers to stay put for long periods of time. Banks that played a dual role as debt-holders and shareholders have at times used their ownership stakes to encourage client firms to take on projects with low profitability instead of preventing asset substitution. Parent firms that controlled a high percentage of the shares in their (listed) subsidiaries were prone to transfer funds from minority shareholders to controlling shareholders (parents firms) instead of encouraging better performance. 
Institutional investors, on the other hand, played a significant positive role in monitoring firms instead of inducing managerial myopia.

Indeed, this study provides evidence that high levels of institutional shareholding (either foreign or domestic) and, somewhat surprisingly, block shareholding by corporations have a positive effect on firm performance. In contrast, bank ownership has had a consistently negative effect on firm performance since the mid-1980s. These results imply the following: 1) institutional shareholders are now playing a significant monitoring role in Japanese firms by taking over some of the tasks previously performed by the (main) banks; 2) the unwinding of cross-shareholding between banks and corporations clearly produces efficiency gains; and 3) although the reasons offered up in the past to justify bank ownership of both equity and loans no longer seem to hold, the economic rationale for high levels of block holding by corporations and cross-shareholding among firms remains valid.

The remainder of this chapter is organized as follows. In the next section, we briefly summarize the evolution of the ownership structure of Japanese listed firms since the postwar reforms. In the third section, we address the causes of this evolutionary change, and examine the determinants of the choice between holding and selling shares by both banks and non-financial institutions. The fourth section highlights the effect of changing ownership structure on performance. The fifth section provides a conclusion and some perspectives on future trends.

\section{Approaching the Stable Shareholder Problem}

\section{The puzzle}

Stable shareholders have usually been considered insiders friendly to share issuers. Or to put it differently, they are shareholders who make implicit contracts with issuers, promising not to sell their shares to unfriendly third parties such as green-mailers or parties who may attempt hostile takeovers, unless the issuers face a severe financial crisis that triggers suspension of dividend payments (Sheard 1994, Okabe 2002).

Defining stable shareholders as corporations and financial institutions that own shares for the long term, we found that the percentage of shares held by them clearly increased in two steps (Figure 1): the first increase occurred from 1950 to 1955, and the second from 1965 to 1974. The post-World War II reforms included compulsory redistribution of corporate ownership centering on 
the dissolution of the zaibatsu. Consequently, block shareholders (zaibatsu family and holding companies) were eliminated, and individual shareholding increased. The Occupation era reforms produced the dispersed ownership structure with the low level of managerial ownership that has characterized postwar Japanese firms. The new managers who emerged to run Japanese corporations were free from effective control by large shareholders but were exposed to the myopic pressures of the stock market. Their response was to seek to stabilize the stock issued by their firms through existing networks. The adage that "shareholders don't choose managers, managers choose friendly shareholders" aptly sums up what happened. Indeed, the fundamental principles of joint stock corporations appear to have been violated. In particular, ex-zaibatsu firms whose stock had been dispersed pressed same-line firms to purchase their stocks. The government also promoted corporate shareholding and encouraged life insurance companies to acquire stock. The movement toward stable shareholding accelerated in the wake of revisions to the Antitrust Law that deregulated shareholding (Miyajima 1995). Consequently, due to sharp increases in shareholding by financial institutions and corporations (friendly insiders), the ratio of stable shareholders increased from $23.6 \%$ in 1950 to $36.8 \%$ in 1955 .

After a period characterized by a relatively stable ownership structure (1956-64), ownership of shares by financial institutions and corporations increased sharply once again, with the stable shareholder ratio climbing from $47.4 \%$ in 1965 to $62.2 \%$ in 1974 . During the period of capital liberalization that followed the stock price decline of 1962, corporate managers feared hostile takeovers by foreign competitors. Consequently, friendly corporations and large banks boosted their ownership stakes in firms, boosting the stable shareholder ratio. In addition, the cooperative stockholding institutions that were originally established to maintain stock prices also promoted shareholder stabilization because they sold their holdings to the affiliates or main banks of the issuers after stock prices recovered. Miyajima, Haramura, and Enami (2003) showed that the changing ratio of shares held by banks or main banks from 1964-69 was positively sensitive not only to existing relationships (measured by the level of (main) bank dependence at the beginning of the estimation), but also to corporate performance (rate of return on assets, or ROA) and growth opportunities (Tobin's q). As delegated monitors, main banks carefully reviewed the credit risks 
and growth opportunities of corporations that offered shares ${ }^{1}$.

On the other hand, non-financial corporations that held onto bank shares were rational actors because the market return on bank shares was stable and usually outperformed the Tokyo Stock Exchange Stock Price Index (TOPIX) ${ }^{2}$. To further encourage stable shareholding, the regulatory framework under the Commercial Code was revised to allow top managers (corporate insiders) to issue new shares by allotting them to friendly third parties without approval from the general shareholders' meeting. To use the terminology of the law and finance literature (La Porta et al. 1998), we could say that protections for minority shareholders were weakened during this phase.

From the early 1970 s to the early 1990 s, the ownership structure of Japanese firms was remarkably stable, as many observers have emphasized ${ }^{3}$. Even after the mid-1980s when the Antitrust Law was revised to lower the ceiling on shareholding by a financial institution to $5 \%$ from $10 \%$, financial institutions increased their total share in Japanese corporations. The stylized portrait of the ownership structure of Japanese firms familiar to most of us is based on this period of stable shareholding. In the 1990s, however, the stable ownership structure was undergoing quiet but important changes. We can observe from Figure 1 that these changes were of significant degree when placed in the context of the postwar evolution of Japanese corporate ownership, and in fact comparable in scale to the transformation of the late 1960s.

To get a grasp of these changes, we will focus on the following questions: Why did shareholding by foreigners begin to increase and stable shareholding decrease in the 1990s? Why did the cross-shareholdings that had been extremely stable begin to unwind from 1995? If the primary motivation for shareholder stabilization was to mitigate the threat of takeover, why did stable shareholding begin to decline just as the takeover threat began to increase following the plunge in stock prices and the rise in foreign ownership of shares? In the following section, we solve this puzzle by taking a close look at the factors that characterized the ownership structure in

\footnotetext{
${ }^{1}$ Miyajima et al. (2003) also reported that (main) bank ownership of manufacturing firms was negatively sensitive to credit risk as measured by the interest coverage ratio. But it should be noted that the positive relationship to ROA and Q is only observed for 1964-69, and not significant in the period from 1969-74. This positive correlation between bank ownership of shares and performance is consistent with Prowse (1990) and Flath (1993), which stress the role of the main bank as delegated monitor, and provide supportive results for the 1980s.

2 See Miyajima et al. (2003) for details.

3 See Prowse (1990), Frath (1993), Sheard (1994), Weinstein and Yafeh (1998), and Yafeh and Yosha (2003).
} 
the 1990 s.

\section{Increase in foreign shareholding}

Table 3 summarizes the value and volume of net selling and buying of shares by category of shareholder. We find that the rise in the fraction of shares owned by foreign investors preceded changes in the Japanese ownership structure. Foreign investors have increased their presence in the Japanese market since 1991, becoming important net buyers, while securities investment trusts turned into net sellers due to the drop in stock prices. One reason for the rise in purchases by foreign investors was the growth in pension funds in the U.S. (see Chapter 2). Ironically, falling stock prices have supported this trend since 1990. As stock prices soared during the asset bubble period, foreign institutional investors representing internationally diversified investment funds considered Japanese stocks to be overpriced. After stock prices fell, however, foreign investors could buy larger volumes of shares with a given pool of money, and began to incorporate Japanese stocks into their portfolios.

\section{$==$ Table 3 about here $==$}

The investment behavior of foreign investors is believed to be affected by a so-called home bias, i.e. the preference for large and well-established stocks (Kang and Stultz 1997, Murase 2001). To confirm this hypothesis, we tested the following simple model:

$$
\Delta F O R_{t}=F\left(F O R_{t-1}, A V Q_{t}, S I Z E_{t-1}, B O N_{t-1}, D A R_{t-1}, D I S T_{t}, I N D\right)
$$

where FOR is the percentage share held by foreign institutional investors ${ }^{4}, A V Q$ is the period average of Tobin's $q$, SIZE is the logarithm of total assets, and $B O N$ is the degree of dependence on bonds (i.e. the ratio of bonds to the sum of borrowing and bonds). In addition, we included leverage, $D A R$, a dummy variable for financial distress, $D I S T$, which is 1 if net profit is negative at least one time in the estimated period, and otherwise 0 , and an industry dummy, IND. The results are presented in Table 4.

Even with this simple estimation, we can observe that firm size, growth opportunity (Tobin's

\footnotetext{
${ }^{4}$ FOR excludes the share held by foreign companies such as Ford-Mazda, Renault-Nissan, and GM-Fuji Heavy Ind.Co.
} 
$q$ ), and degree of dependence on bonds have significant positive effects on foreign ownership while leverage and financial distress have negative effects. Foreign investors increased investment in both large firms and growing firms with low default risk and high bond dependency. Moreover, comparing the two half-periods (1989-94, and 1994-99), we can see that SIZE and BON had a larger effect in the former half-period. This implies that investors targeted large and established firms. On the other hand, after 1995, the estimated effect of $A V Q$ and DIST improved, implying that investors increasingly took corporate performance into account in the late 1990s.

$$
==\text { Table } 4 \text { about here }==
$$

\section{The sale of financial institution shares by corporations}

The increase in foreign investors forced incumbent managers to act in the interests of general shareholders and thus to reconsider cross-shareholding arrangements. At the same time, the need to keep firms in sound financial health in order to earn high credit ratings played an important part in encouraging managers to review their securities portfolios. Moreover, with the drop in stock prices after 1995, the rate of decline of bank share prices started to exceed TOPIX's decline, reflecting the failures of several local banks and jusen housing loan companies, and the price correction triggered by the Daiwa Bank incident in the fall of 1995 (Ito and Harada 2000). The timing of this change in bank shares prices, which had previously been synchronized with TOPIX, corresponded to the appearance of a Japan premium in the inter-bank market (Peek and Rosengren 2001).

$$
==\text { Figure } 2 \text { about here }==
$$

Figure 2 not only shows that the gap between the performance of bank shares and TOPIX widened since 1995 but also that the bank share price trend began to deviate from that which prevailed during the formative period of stable shareholding (1965-74), when bank shares had a higher return on investment than TOPIX (Miyajima et al. 2003). We can infer that because of both the decline in market returns of bank shares and the increased risk associated with holding onto them, firms for the first time in the postwar period had to confront the problem of whether or not to sell bank shares. According to Figure 3, however, which summarizes the ratio of bank shares sold during the fiscal year to shares held by corporations at the beginning of the period (henceforth, the 
corporate rate of selling; see Figure 3, note 2) ${ }^{5}$, the corporate rate of selling in 1995 and 1996 did not grow significantly when compared with previous periods. Indeed, only a limited number of firms sold their bank shares.

However, the importance of the corporate choice to sell off bank shares or not increased significantly from the end of 1997 to the beginning of 1999. This period saw the bankruptcies of Hokkaido Takushoku Bank (November 1997), Yamaichi Securities Co. (November 1997), Long-Term Credit Bank of Japan (October 1998), and Nippon Credit Bank (March 1999). As the gap between bank share returns and TOPIX widened, the Japan premium rose and the credit ratings of the major commercial banks dropped. By February 1999, the index for bank shares was 53.8 (compared to 100 in March 1995), which was far below the 85.6 for TOPIX. It became apparent that bank shares not only offered low rates of return but also carried high levels of risk. Furthermore, the introduction of consolidated accounting (implemented in 1999) and current value accounting put even more pressure on corporations to sell their bank shares. Consequently, the rate of corporate selling of bank shares has been increasing since 1997 and exceeded $20 \%$ in 1999 .

\section{$==$ Figure 3 about here $==$}

\section{Banking crisis and its impact}

As corporations sold their financial institution shares, banks and other financial institutions began to unload their corporate shares. Insurance companies led the way, turning into major net sellers, especially after the banking crisis worsened in 1997 (Table 3). It is said that domestic institutional investors, including life insurance companies, changed their behavior in response to the increased emphasis that was placed on fiduciary duty in the late 1990s.

Moreover, banks, which had been net buyers from 1991-96, turned into large net sellers. The rate of selling rose to over 10\% by 1997 (Figure 3). Factors influencing this trend included both the need to dispose of non-performing loans and to satisfy BIS rules as well as the introduction of current value accounting. Also important was that bankers had begun to recognize that their

\footnotetext{
${ }^{5}$ We consider a reduction in the number of shares during the period to be a sell-off. We arrived at a figure for sell-offs by comparing the number of shares held by corporations (after adjusting for capital transfers) at the beginning and end of the firm year. The ratio of selling is computed by dividing the number of sell-offs by the total number of recognized cross-shareholding relationships.
} 
holdings of corporate shares had become lightning rods for criticism. Under BIS rules that required banks to calculate Tier 1 capital by including unrealized capital gains and losses from shareholdings, shares held by banks (estimated to be almost twice Tier 1 capital in 1999) were expected to have a tremendous impact on their lending behavior as stock prices declined, triggering a credit crunch. The banking crisis in late 1997 marked an important turning point for Japan's corporate ownership structure, as public and policy attitudes toward cross-shareholding clearly changed from supportive, or at least neutral, to critical and unsupportive.

\section{Banks' Shareholding Restriction Law}

Although a second injection of public funds in March 1999 was supposed to help banks put their non-performing loan problem behind them, the loans still posed serious challenges into 2001 . The government's response to the lingering problem was to enact policies to dissolve cross-shareholding. In April 2001, new regulations on banks' Tier 1 capital shareholdings were implemented as part of an emergency economic package. In addition, the Banks' Shareholding Restriction Law was enacted in September, with a targeted implementation date of September 2004. Major banks' shareholdings were 1.5 times Tier 1 capital in March 2001, so they were required to reduce their shareholdings by 10 trillion yen. Because a bridge bank would be needed to handle the sale of shares by major banks, the Banks' Shareholdings Purchase Corporation (BSPC) was established and started purchasing shares in February 2002. Also, revisions to the Commercial Code abolished restrictions on share buy-backs and treasury stock, allowing firms to hold onto their shares after acquiring them. While banks and corporations continued to sell off their mutually held shares at a brisk pace, the banks' selling rate increased rapidly. Although the corporate selling rate had been at least as high as that of the banks for most of this period, banks began selling off shares at a higher rate than corporations in 2000, with their selling rate reaching $40 \%$ in 2001 .

\section{Determinants of the Unwinding of Cross-shareholding}

\section{3-1. The Data}

As described above, there was a general decline in cross-shareholding but the changes in the shareholding structure did affect firms uniformly. What are the firm characteristics that 
encouraged a firm to either unwind cross-shareholding relationships, or to maintain them at current levels? Given that corporations were relatively more likely to maintain cross-shareholding relationships with other corporations in the 1990s than with banks, as is shown in Table 1, we focus our analysis below on cross-shareholding relationships between corporations and banks. Our data set is based on the Survey of Cross-Shareholding conducted by the NLIR since 1987. The data allows for rigorous analysis of individual cross-shareholding relationships between corporations and banks ${ }^{6}$.

This analysis is concerned with yearly changes in cross-shareholding from FY 1995 (March 1995) to FY 2001 (March 2002). Recall that the banking crisis of 1997 increased both banks' and corporations' tendencies to sell off mutually held shares and that the Banks' Shareholding Restriction Law that was under discussion from 1999 provided banks with further incentive to unwind cross-shareholdings. In the following analysis, in addition to making estimates for the entire period from FY1991-FY2001, we conduct separate analyses for three sub-periods: period I, FY 1995-96; period II, FY 1997-98; and period III, FY 1999 and after.

Our data set has two parts: non-financial corporations that are listed in the First Section of the Tokyo Stock Exchange ${ }^{7}$, and commercial banks. The latter includes major commercial banks and long-term credit banks that went public by the end of each year of observation. We exclude trust banks since it is not possible to separate shares that they hold as assets and shares held in trust for customers. We also exclude banks that have been de-listed from the stock exchange due to bankruptcy and nationalization, e.g. Hokkaido Takushoku Bank in 1997 and Long-Term Credit Bank of Japan in 1998, because it was not clear who owned the shares held by these institutions.

Because we focus on the choices made by corporations (to sell bank shares) and banks (to sell corporation shares), we limit our analysis to matters related to a corporation's holding of bank shares at the beginning of each period, and to a bank's holding of corporate shares at the beginning of each period ${ }^{8}$. Thus, the sample size decreases each year.

\footnotetext{
${ }^{6}$ Refer to http://www.nli-research.co.jp/eng/resea/econo/eco031118.pdf for more detailed information on the cross-shareholding data.

7 Firms that merge with the other listed firms during an observation period are excluded from the sample for the year of the merger since it is difficult to capture the change in shareholdings.

${ }^{8}$ During the time period of this analysis, large banks were being integrated into bank groups (centered on holding companies), making it more difficult to trace the bank-holding company shares held by corporations
} 
For the beginning point (March 1995), the data include 14 banks and 1,087 corporations. Within this sample, there are 1,065 corporations that issued shares held by banks and 1,067 corporations that held bank shares. The data reveals that cross-shareholding relationships were widespread: 1,039 corporations, or $95 \%$ of the sample, had cross-shareholding relationships. Furthermore, the cross-shareholding relationship for each corporation was not limited to one bank. On average, corporations held shares in 5.4 banks at the beginning of this period. There were 5,879 instances of bank share ownership by corporations. If we limit our focus to mutual shareholding cases, corporations held shares in an average of 3.2 banks in 3,545 instances. Henceforth, the unit of analysis will be the shareholder's decision to sell or hold shares.

\section{3-2. Corporate decision on holding bank shares}

We begin our analysis by examining the non-financial corporation's decision to sell off bank shareholdings at a time when holding onto these shares is increasingly associated with higher risk and lower market returns, as described above. In general, a firm's current portfolio, liquidity constraints, and banks' creditworthiness ratings all affect the decision to sell. Additionally, other factors might also come into play. The first is capital market pressure as represented by the credit ratings on corporate bonds. The importance of bond financing has increased since the late $1980 \mathrm{~s}$ such that maintaining at least a BBB rating became critical for corporate financing in the 1990s. Given capital market pressures, selling bank shares signaled a rational management style that put an emphasis on ROE and transparency. However, firms that sought to unwind cross-shareholding relationships also faced retaliation from banks that could sell off massive blocks of corporate shares. Thus, corporations may have decided to hold onto their bank shares and accept the higher financial risk. Additionally, managers whose firms were likely takeover targets might have been reluctant to sell as well.

To test the above hypotheses, we estimate the Logit model below that explains a corporation's

at the end of the period to the bank shares they had owned at the beginning of period. Therefore, we analyze the relationships between corporations and bank groups by using the total amount of loans and total shares held by group banks as proxies for the relationship between corporations and the bank group. For instance, in the case of Mizuho Holdings, established in September 2000, firms which held shares in any of the following banks - Industrial Bank of Japan, Fuji Bank, and Dai-Ichi Kangyo Bank - as of March 2000 are considered to own Mizuho Holdings' shares as of March 2001, and are treated as having owned Mizuho Holdings' shares from the beginning of period. 
decision to sell off bank shares based on the following variables: 1) the need to sell, $X_{1}, 2$ ) the financial health of the bank, $\left.X_{2}, 3\right)$ pressure from capital markets, $\left.X_{3}, 4\right)$ potential threat of takeover, $X_{4}$, and 5) the relationship to the bank, $X_{5}$.

$$
C S L_{i j}=F\left(X_{1}, X_{2}, X_{3}, X_{4}, X_{5}\right)
$$

The dependent variable $C S L_{i j}$ represents the decision of corporation i on holding bank j's shares. It takes the value 1 if in the current period we observe the selling of shares which were held at the beginning of period (reduction of shares held), and 0 otherwise. The definitions of explanatory variables $X_{1}-X_{5}$ are in Appendix $1^{9}$. Table 5 presents the estimation results ${ }^{10}$. To show the magnitude of each explanatory variable on the sell-off rate, we provide the estimated marginal effect multiplied by one standard deviation in Table 5 (column $X^{*} \mathrm{dP} / \mathrm{dX}$ ). For instance, 0.030 for $X_{1}, D / E$, means that when this variable increases by one standard deviation above its mean, the probability of sell-off increases approximately $3 \%$ points.

\section{$=$ Table 5 about here $=$}

First, we found that each corporation's choice to hold bank shares is determined by perceived need to sell. The coefficients on the variable $D_{-} I C R$, a proxy for the degree of need to sell off bank shares for liquidity reasons, and the variable $D / E$, the ratio of debt to equity, are both positive and significant at the $1 \%$ level. Firms facing a liquidity crisis or excess debt risk are more likely to sell their bank shares. The coefficient on $B S V / A$, which was included to capture the skewness of an equity portfolio for specific bank shares, is also positive and significant. This indicates that firms are more likely to sell off bank shares when those shares are their main assets. The magnitude of the coefficient of $B S V / A, 4.5 \%$, is larger than that for other variables. When observed over our three periods, it increases from $2.3 \%$ to $3.6 \%$ to $6.2 \%$. This implies that bank shares are increasingly being viewed as risky assets. This result is consistent with our conjecture that high

\footnotetext{
9 In our following analysis, when treating outliers for all explanatory variables except dummy variables, we replace all the values deviating more than three standard deviations from sample means with sample means plus three standard deviations.

${ }^{10}$ In addition to them, we introduce a variable $D_{-} B M$, a dummy variable which takes the value of 1 if several banks which are separate entities in the beginning of period are integrated by the end of period, to control for the effect of bank mergers. We also add year dummy, $D_{-} Y Y$, which controls for the year effect.
} 
risk is one factor that increases a corporation's tendency to sell off bank shares.

A corporation's choice to sell its bank shares is also determined by the financial health of the bank in which it holds shares. The positive and significant coefficient on $X_{2}, D_{-} F R D$, implies that less financially healthy banks tend to be candidates for a sell-off. The reduction of holding risk appears to be one of the main factors in this choice. Also, the effect becomes larger as time passes within the period of observation. The banking crisis apparently triggered a rising awareness of the risk of holding bank shares.

Now let us focus on $X_{3}$ through $X_{5}$. The coefficient on $X_{3}$ supports the view that firm managers that issued bonds in the beginning of each period needed to sell bank shares in order to send signals to the market to maintain or raise their credit ratings. Notice that firms with at least a BBB rating, generally considered the prerequisite for issuing bonds, had a $1.4 \%$ higher probability of selling. This implies that maintaining and improving a good credit rating is a vital concern for those firms. Also, $D_{-} C R B$ has a greater effect in period III. The results support the conjecture that it became increasingly critical for firms to keep or improve their credit ratings after 1999, when foreign rating agencies imposed stricter requirements for BBB ratings and the probability of default among listed firms increased.

On the other hand, estimation results for $X_{4}$ indicate that the threat of a hostile takeover restrained the unwinding of cross-shareholding. The coefficient for the total market capitalization, $L E M V$, is positive and significant at a magnitude of $1.9 \%$. Firms with a small current value of total shares appear to accept the increasing risk of holding bank shares to avoid retaliatory sell-offs. In addition, the coefficient on the ratio of non-stable shareholders, NOST, is significantly negative, implying that firms susceptible to hostile takeovers tend to keep their cross-shareholding relationships with banks.

Last, the estimation results for variable $X_{5}$, which captures relationships with banks, mostly support the conjecture that firms with strong relationships with banks are less likely to liquidate bank shares regardless of holding risk. For example, the coefficient on $B B R$, a proxy of dependency on bank loans, is significantly negative. This suggests that firms avoid selling off shares of banks on which they depend for financing. Note that the magnitude of this effect grows larger after the banking crisis. Firms could not sell bank shares in spite of the higher holding risk, given the possibility that funding could be withdrawn. 
The coefficient on $B H R$, a proxy for a firm's dependence on a bank (on the equity side), is also significantly negative and large at $3.4 \%$. Thus, if the bank is a block holder, then the firm tends to avoid selling off the bank's shares. This effect is significantly negative in period II, after the banking crisis occurred. It implies that firms chose to hold shares from banks that were their important stable shareholders, fearing retaliatory sell-offs by banks in the late 1990s.

In sum, corporations considered not only equity portfolios or their liquidity needs, but also the risk of holding bank shares, the threat of takeover, and their long-term relationship with banks when choosing to sell off bank shares. The fact that high dependence on banks (for both equity and loans) has a negative effect on the decision to sell is especially important. Even as selling bank shares became an increasingly rational choice, some firms chose to maintain cross-shareholding if capital market pressure was weak, the possibility for hostile takeovers was relatively high, or if there was a strong pre-existing relationship with a bank. However, one variable of $X_{5}, D_{-} M B$, which represents main-bank relationships, has a positive and significant coefficient in period II. This does not support the hypothesis that firms avoided unwinding cross-shareholding with banks with which they had strong relationships. Why then did firms choose to unwind cross-shareholding with main banks, which were considered to have the closest relationships to firms? We return to this question in a later section.

\section{3-3. Bank decision on selling of corporate shares}

As noted above, the selling off of corporate shares by banks began after 1997. In this section, we will address why banks chose to sell.

Although identifying the determinants of the investment behavior of banks in general terms is not a simple exercise, we can assume that banks do not sell shares based merely on the fact that they may have determined that their holdings of a certain stock are excessive compared to their overall market portfolios or that the stock has low liquidity. They also will prefer to sell risky shares, since banks rely on deposits as a source of investment funds. Furthermore, following Flath (1993) and Prowse (1990), we predict that banks tend to hold shares of firms with high growth opportunities because banks feel a need to monitor managers of firms that have afforded their managers a considerable degree of discretion.

On the other hand, it is highly plausible that a bank's decision to sell is strongly influenced by 
its financing and shareholding relationship with a given firm. This is particularly reasonable if the bank is the firm's main bank. Additionally, if there is an urgent need to secure funds in order to eliminate a non-performing loan, banks may skew their selling toward shares of firms with high share prices. Bank behavior based on such (perverse) incentives leads to negative influences on corporate governance for corporations as well as the deterioration of their portfolios.

To test our conjectures, we estimate the following simple Logit model that measures a bank's choice to sell corporate shares with the following variables: 1) the bank's portfolio factor and its need to sell, $\left.Z_{1}, 2\right)$ market pressure on the bank, $\left.Z_{2}, 3\right)$ the growth potential and risk level of given firms, $Z_{3}$, and 4) the strength of the relationship with the given firms, $Z_{4}$.

$$
B S L_{i j}=F\left(Z_{1}, Z_{2}, Z_{3}, Z_{4}\right)
$$

The dependent variable $B S L_{i j}$ shows whether bank $\mathrm{j}$ sells or holds shares of corporation $\mathrm{i}$. It is 1 if in the current period we observe the selling of shares held at the beginning of period (reduction of shares held), and 0 otherwise. The definitions of explanatory variables $Z_{1}-Z_{4}$ are in Appendix 2 . Table 6 presents the estimation results.

\section{$=$ Table 6 about here $=$}

The variables of $Z_{l}$ explain a bank's need to sell shares. Both $B H R / T 1$, a proxy of the bank's portfolio factor, and $L E M V$, a proxy for liquidity, have positive coefficients as expected. The magnitude of $L E M V$ is large at $2.7 \%$. Banks selected both over-invested company stocks and those that are easier to sell due to high liquidity as targets for sell-off. Also, in time-series, these trends are stronger in period III. Until the banking crisis, banks refrained from selling shares of corporations for which they were the main shareholders. This implies that the banks' level of awareness of holding risks was low. However, in period III, when public policy promoted the unwinding of cross-shareholding relationships, the need to reduce holdings became an important determinant in explaining a bank's selling behavior.

On the other hand, $Z_{2}$, which tests the market's evaluation of banks' financial health, has a strongly positive and significant coefficient in period $\mathrm{II}^{11}$. When we divided sample firms into two

11 In period III, this variable has a significantly negative coefficient, which seems to represent the effect 
groups by financial health and compared the probability of sell-off between them, we found that the probability of sell-off for a less healthy bank was $15.6 \%$, whereas that of a healthy bank was much smaller at $9.3 \%$. Thus, it appears that those banks that took market and rating agency evaluations of firms seriously believed that it was important to send strong signals by reducing shareholding risk.

Having made the above observations, we turned our focus to how banks evaluated a firm's risk or quality in choosing corporate shares to sell off. From the results for $Z_{3}$, we found that banks' risk consideration declined following the banking crisis. The coefficient of the variable DICR, which represents a firm's credit risk, is positive in the estimation for both the whole period and in period I. However, in period III, when disposal became widespread, the coefficient is statistically insignificant. More importantly, the coefficient of the variable $D / E$, another proxy of a firm's credit risk, is positive in the period I, but becomes negative in period II and significantly negative in the last period. Thus we can infer that banks that sold high-risk shares until period I became less concerned about the risks of holding shares in periods II and III, when disposal was highly imperative $\mathrm{e}^{12}$

On the other hand, the coefficient of $D_{-} A V Q$, a proxy for the expected return or growth opportunity of a stock, is insignificant until period II. However, rather surprisingly, it becomes significantly positive in the period III. As explained above, according to standard agency theory, D_AVQ should have a negative sign. However, banks sold high value shares systematically. To put it differently, as banks were required to reduce their holding shares, they sold firms with high market valuations rather than riskier firms. We can conjecture that, since 1999, when financial health became their primary concern, banks started to give priority to securing funds to eliminate non-performing loans. This resulted in a systematic deterioration of banks' equity portfolios.

Last, the result for $Z_{4}$ in Table 6 strongly supports the hypothesis that a long-term relationship with a firm influences a bank's decision to sell off shares. The coefficient on $B B R$, a proxy for the closeness of financing relationships, and the coefficient on $D_{-} C S H$, which represents

from in-kind contributions of diverse stocks to ETF in 2001 by Tokyo Mitsubishi Bank, which has a high financial rating. In fact, if we exclude it from the sample, the coefficient becomes significantly positive.

${ }^{12}$ We observe that the effect of SDRTN, which represents stock price fluctuation risk, has strengthened after period II. This result is likely to mean that the reduction of stock holding risk is an important factor in recent decision-making on sell-offs. 
cross-shareholding relationships, and the coefficient on $D_{-} M B$, which represents main-bank relationships, are all significantly negative at the $1 \%$ level. As far as $B B R$ is concerned, its coefficient is significantly negative at the $1 \%$ level in all periods, although the effect is stronger in period II when the banking crisis occurred. If a firm's degree of dependence on bank loans is one standard deviation (10.9\%) higher than the mean (12.5\%), then the bank's probability of selling declines by $3.4 \%$ points. This is more than $30 \%$ of the $10.5 \%$ probability of selling in period II. Based on these results, we conclude that banks chose to maintain cross-shareholding with firms with which they had formed strong relationships.

As shown above, a bank's decision to sell off a stock is determined not only by its concern for adjusting its portfolio, but also by its long-term relationships with firms. Especially after the banking crisis, banks that received poor market valuations began to sell shares actively, and their decision to sell was based more on the nature of their financial relationships with firms than on the credit risks of those firms. Moreover, after 1999, while banks reduced shareholding mainly by selling shares with higher liquidity and higher expected rates of return (those which were easy to sell), they held onto shares of firms with which they had long-term relationships. This was especially true in cases where main-bank relationships existed. In this sense, banks' investment behavior was based on a perverse incentive which not only undermined corporate governance but also degraded their own portfolios.

\section{3-4. Cooperative and non-cooperative unwinding}

As described in the preceding sections, even as shareholding risk has come to be clearly recognized in recent years, banks have tended to refrain from selling corporate shares of firms with which they have formed long-term relationships. In particular, when cross-shareholding relationships existed, the threat that one side's sell-off of shares would invite a retaliatory sell-off by the other was one factor that helped to maintain cross-shareholdings. We now shed light on the question of whether cross-shareholding was terminated under an implicit contract between both parties (cooperative unwinding) or under circumstances in which one party's actions invited a retaliatory sell-off by the other (non-cooperative unwinding).

To determine whether the unwinding of cross-shareholding happened cooperatively or not, we need to deepen our analysis and take the actual negotiation process into account. Given that the 
mutual shareholding as such is a form of implicit contract, in cases where shares were sold simultaneously it is likely that the termination of the relationship is determined by an implicit agreement by both sides to do so. When there was a lag in the timing of the choice, however, we will assume that one side made a choice to sell off independently of the other, and was subjected to retaliatory action. Under these assumptions, we introduce a dummy variable $X_{6}$ to represent bank $\mathrm{j}$ selling corporation i's shares in the current or previous year into equation (1) in Section 3-2.

We also introduce the dummy variable $Z_{5}$ to represent corporation i's selling bank j's shares in the current or previous year into the bank's shareholding choice model ((2) in Section 3-3). Of the 2,074 instances of shares sold by corporations in the entire period, there were 718 instances in which the partner bank sold off in the same year $(B S L)$, and 304 instances in which the partner bank sold off in the previous year $(P B S L)$. On the other hand, of the 2,728 instances of shares sold by banks for the entire period, there were 718 instances in which the partner corporation sold off in the same year $(C S L)$, and 440 instances in which the partner corporation sold off in the previous year $(P C S L)$. The estimation results for the entire period are shown in Model 2 in Table 5 and Table 6. The estimation results by period are shown in Table 7 (only results for the dummy variables are reported). Although this estimation cannot identify sell-off behavior stretching over multiple years, we can make two observations from these results ${ }^{13}$.

\section{$=$ Table 7 about here $==$}

First, both a bank's and a corporation's choice of stocks to sell responds to the variable which represents the choice to sell by the other party in the same year. For instance, the marginal effect on $B S L$, a bank's sell-off in the same year, is $5.1 \%$. On the other hand, the marginal effect on CSL, a corporation's sell-off in the same year, is $6 \%$. Recent instances of cross-shareholding termination appear to have proceeded cooperatively, seemingly under implicit contracts agreed to by both parties.

Second, there is evidence, however, that cross-shareholding relationships also end non-cooperatively. The variables representing sell-offs by the other party in the previous year have significantly positive coefficients in the entire period sample. The lag effect is in general much smaller than same-year effects, and the lag effect of a bank's sell-off $(P B S L)$ on corporate choice is

13 Since banks have a large shareholding ratio in each firm, they presumably sold parts of their shares in multiple periods. 
quite small and insignificant until period II. On the other hand, a bank's choice to sell in response to the disposal of corporate shares in the previous year (PCSL) is significantly positive but only after period II. This implies that a corporation's choice to sell, considering the rise of holding risk, strongly influences a bank's choice. In summary, the results show that there was both a cooperative effect and a non-cooperative effect, whereby corporations sold their bank shares first and banks retaliated. This supplementary factor led to a rapid disintegration of many cross-shareholding relationships.

\section{3-5. Influence of the main-bank relationship on choice}

The relationship between a corporation and a bank is generally stronger when the bank is the corporation's main bank. In fact, banks tended to refrain from selling shares of firms with which they have had a main-bank relationship. However, estimation results for corporations show that they were more likely to sell shares of their main bank. This counter-intuitive result is a puzzle. How did main-bank relationships affect sell-off behaviors? Why did corporations liquidate main-banks' shares and why was that possible?

In the following, we estimate models that include the interaction term of the main bank dummy $D_{-} M B$ with the interest coverage ratio, $D_{-} I C R$, and the bank's financial rating, $D_{-} F R D$. Here, $D_{-} I C R$ represents the necessity to sell for corporations and the holding risk for banks, respectively. In contrast, $D_{-} F R D$ represents the necessity to sell for banks and the holding risk for corporations. This estimation allows us to test the conjecture that even though the choice to sell a bank stock is financially rational, a sell-off is avoided when the main bank relationship is strong. The results for corporation choices are presented in Model 3 of Table 5.

First, we find that that the estimate for the interaction term between $D_{-} F R D$ and $D_{-} M B$ has a significantly negative coefficient. This result shows that, although the financial condition of banks in which corporations invested got worse and their holding risk increased, corporations tended to avoid selling a bank's shares if they had a main-bank relationship with that bank.

Second, we should note that the coefficient of the interaction term between $D_{-} M B$ and $D I C R$, a proxy of the financial degradation of shareholding corporations themselves, is significantly positive. Corporations facing liquidity crises tend to selectively liquidate shares of their main banks. When we divide the sample into two sets, one with cross-shareholding with main-bank 
relationships and the other without, and estimate equations (1) in two sets respectively, we achieve mostly the same results as above. Therefore, under main-bank relationships, corporations liquidated shares of their main bank (in other words, in cases in which the main bank did not stop the sell-off) only when the corporations experienced a financial crisis, which produced the puzzling outcome mentioned above.

On the other hand, estimation results for banks (Model 3 in Table 6) show that the main-bank relationship restrains a bank's sell-off of shares of partner corporations. The coefficient of the interaction term between the firm partner's financial condition and the $D_{-} M B$ dummy $\left(D_{-} M B^{*} D_{-} F R D\right)$ is significantly negative. This implies that even though a bank's unhealthy financial condition may cause increasing market pressure to reduce shareholding, the bank tends to selectively hold shares of corporations with which it has a main-bank relationship. Also, the coefficient of the interaction term between a corporation's credit risk and the $D_{-} M B$ dummy $\left(D_{-} M B^{*} D_{-} I C R\right)$ is significantly negative. This is especially so in period III (not reported). This result suggests that the bank tends to avoid selling off shares of corporations with high credit risk if the bank has long-term relationships with those corporations ${ }^{14}$.

The puzzling asymmetrical response between banks and corporations in selling their partners' shares can be explained by the bail-out efforts of the main bank. Since banks deeply value a main-bank relationship, they permit these corporations to liquidate their bank shares in a crisis. In contrast, they hold onto their shares of a corporation in crisis since selling would send a clear signal to the market that the corporation is in bad financial shape.

Consequently, the asymmetric effect of the main-bank relationship further accelerated the degradation of a bank's equity portfolio. As discussed above, banks mainly liquidated shares of corporations with high expected rates of return, regardless of the level to which credit risk skewed their equity portfolio to firms with low rates of return. Moreover, the above results show that banks held shares of the corporations with which they were the main bank in order to maintain a long-term relationship, even when corporations presumably face financial crisis.

\footnotetext{
14 The same result can be observed from the estimation in which the sample is divided into main-bank firms (firms with main banks) and non-main-bank firms.
} 


\section{Effect of Ownership on Corporate Performance}

\section{4-1. The costs and benefits of cross-shareholding}

So far, we have examined the causes of the recent rapid unwinding of cross-shareholding. What then are its welfare implications? In this section, we address this issue by examining the relationship between ownership structure and corporate performance.

The growth of Japanese firms up to the 1990s has been credited in part to the existence of stable shareholders. These stable shareholders, according to this theory, freed managers from both the threat of hostile takeovers and myopic shareholder pressures, allowing them to focus on long-run decision-making (Abegglen and Stalk 1985 , Porter 1992, Odagiri 1992). Moreover, many corporate activities are supposed to run efficiently under a high level of cross-shareholding. It provided incentives to employees with firm-specific human capital by protecting them against adverse shocks, and therefore reducing risk (Aoki 1988, Aoki and Patrick 1994, Sheard 1995 , Okabe 2002).

Bank ownership of borrowing firms could also help banks to monitor and mitigate asset substitution problems, thereby improving firm performance. Prowse (1990) and Flath (1993) examine patterns of bank shareholding in Japan as a proxy of bank monitoring. Some previous studies addressing the effect of financial ownership on corporate performance showed that shareholdings by financial institutions improved management efficiency (Lichtenberg and Pushner 1994) and attributed this improved efficiency to effective monitoring.

The role of large shareholders (parent firms) is also supposed to play a significant monitoring role in the corporate governance of Japanese firms. Sheard (1989) addresses the significant role of large shareholders (parents firms) and main banks in Japanese firms. Kang and Shivdasani (1995), and more recently Morck, Nakamura and Shivdasani (2000) confirmed this understanding. Focusing on entertainment expenses, Yafeh and Yosha (2003) show that concentrated shareholding is associated with lower expenditures on activities with a potential to generate private benefits for managers ${ }^{15}$.

In the mid-1990s, however, when it became evident that the Japanese economy faced prolonged stagnation, the costs of Japan's unique ownership structure came under scrutiny.

15 They conclude that large shareholders are probably more important than banks for monitoring. 
Because stable shareholders faithfully held shares over long periods, cross-shareholding almost by definition could potentially foster a moral hazard among incumbent managers (insider control). As management became entrenched, this resulted in low performance due either to over-investment or low effort levels in relation to capital and labor input. ${ }^{16}$ The agency cost associated with cross-shareholding may become even more acute than in cases of high managerial ownership with managers wielding controlling interests in their companies. ${ }^{17}$

It is also plausible that bank ownership could play a negative role in corporate governance when banks use their stakes to encourage client firms to take on projects that deviate from value maximization rather than taking steps to reduce asset substitution ${ }^{18}$. Weinstein and Yafeh (1998) first suggested that banks both induced clients to borrow more than profit maximization warranted and encouraged them to adopt low-risk and low-return investment strategies. Subsequently, Morck, Nakamura, and Shivdasani (2000) stressed that assigning the task of corporate governance to banks does not always lead to maximization of firm value because banks as creditors have different objectives from banks as shareholders. Focusing on FY 1986, the year before the ceiling on a bank's ownership was reduced from $10 \%$ to $5 \%$, they found that equity ownership by the main bank and firm value are inversely related. They suggested that higher bank ownership is associated with relaxed financial constraints, allowing firms to undertake more marginally acceptable investment opportunities. In the same vein, Miyajima et al. (2001) report that corporate investment was sensitive to internal funds only among firms with low growth opportunities in the late 1980s, and that this relationship was stronger among the firms with high ratios of shares held by main banks.

\footnotetext{
${ }^{16}$ For instance, the sensitivity of dividends to profit among Japanese firms has declined to almost zero since the late 1960s when stabilization progressed. It is true that adopting a dividend policy less sensitive to profit may promote firms' investment when firms have high growth opportunities. However, if firms' growth opportunities are low, then adopting such a dividend policy generates free cash flow in Jensen's (1986) sense. In the late 1980s, during the so-called bubble period, low dividends may have emerged as a source of the excessive investment problem.

${ }_{17}$ When managers have a high degree of ownership, they suffer losses when there is empire-building or effort aversion, while in cases in which there is a high level of cross-shareholding, incumbent managers have not been held responsible for any losses associated with such morally hazardous behaviors.

18 The concern with ownership's effect on corporate efficiency is relatively new, while many previous studies have shown that firms belonging to bank-centered corporate groups performed significantly worse than independent firms (Caves and Uekusa 1976, Nakatani 1984, Weinstein and Yafeh 1998). In these analyses, the main instrument by which groups influenced corporate performance was the rent extracted by banks with strong bargaining power.
} 
Another possible cost to Japanese firms belonging to vertically integrated corporate groups (keiretsu) is the conflict of interest between large shareholders (parents firms) and minority shareholders. A growing literature has blamed corporate groups for the expropriation of minority shareholders. Classens et al. (1999) and Johnson et al. (2000) argue that corporate groups are associated with minority shareholder exploitation in Asia. If this argument were applicable to the vertical corporate groups in Japan, it is likely that parent firms with a high ownership stake in subsidiaries (listed subsidiaries) could transfer funds from minority shareholders to controlling shareholders, lowering performance. ${ }^{19}$

The consensus view has seemingly moved from highlighting the benefits of the ownership structure of Japanese firms to stressing its costs. However, so far there has been little empirical research on whether ownership structure affects corporate performance. The limited studies that have been carried out only cover the late 1980s. Furthermore, there is no research that directly addresses the effect of cross-shareholding on performance.

\section{4-2. The Data}

To fill this gap, we focus on the relationship between ownership structure and performance after the bubble period, using the comprehensive database developed by NLIR and Waseda. This database has a wide range of advantages over the data sets used in previous studies, which often depend on information disclosed in financial reports (Yukashōken-hōkokusho). For instance, previous research used "shares held by financial institutions" as a measure of the ownership stake of banks or "stabilized" shareholders. However, needless to say, "shares held by financial institutions" in financial reports includes various types of financial institutions: city banks that are characterized by their joint ownership of debt and equity, trust banks whose shareholdings were mainly comprised of pension and investment trust funds, and the insurance companies that hold shares in both their general account (where they assume the risk) and special accounts (where risk is delegated). Additionally, "shares held by non-financial institutions" in the report also includes both those shares held by business partners (group firms) and block holders such as parent companies.

19 Low performance is also plausible if the monitoring of a listed subsidiary by a parent firm were so strict as to deprive managers and employees of incentives (Burkart, Gromb and Panunzi 1997). 
By contrast, the NLIR-Waseda database, which is constructed on the basis of lists of the 20 largest shareholders for individual firms, provides the accurate shareholding ratio of each stakeholder in line with standard economic theory. Thus, it provides the ratio of stable shareholders by aggregating the shares held by banks (excluding trust banks), shares held by insurance companies and the shares held by non-financial institutions (definitions are provided in Table 1). Consequently, we can disentangle the overall effect of the stabilization of shareholders and that of bank ownership on corporate performance.

Second, the NLIR-Waseda database also provides the accurate ratio held by institutional shareholders, both foreign and domestic. It presents the exact ratio of shareholding by foreign institutional investors by distinguishing shares held by foreign financial and non-financial corporations ${ }^{20}$. It also estimates the shareholding ratio of domestic institutional investors by aggregating the increasingly large number of pension and mutual funds entrusted to domestic financial institutions (mainly trust banks and insurance companies).

Last, this data provides the shares held by main banks and large shareholders among non-financial institutions. The main bank is defined as the largest lender to client firms, while the threshold of the ownership stake of the large shareholder is set at $15 \%$. This data made it possible for us to identify which effects, costs, and benefits dominated in cases of ownership by main banks and large corporate shareholders.

\section{4-3. Results and Discussion}

Our sample firms are the non-financial firms in the First Section of the Tokyo Stock Exchange. ${ }^{21}$ We conducted estimates for the firm years from 1985 to 2002 . This period is further divided into three sub-periods: the bubble (1985-1990), post-bubble (1990-1997), and the banking crisis period (1995-2002). We use the standard model that regresses corporate performance on fundamental variables as well as governance variables including ownership structure, following studies by Richtenburg and Pushner (1994), Yafeh (2000), and Horiuchi and Hanazaki (2001).

\footnotetext{
${ }^{20}$ Previous research used the foreign ownership ratios in financial reports, which include both the shares held by foreign institutional investors as well as foreign non-financial companies (for example, Renault and Ford)

${ }_{21}$ We also conducted estimates for all 2,600 listed firms with the same sample period. The results are basically the same.
} 
Given that our data has a panel structure, we employ a fixed effect model to control for time-invariant unobserved individual (firm specific) effects ${ }^{22}$. The estimated model is:

$$
P_{i, t}-P_{\bar{J}, t}=\alpha_{i}+\sum \beta G o v_{i, t-1}+\chi \operatorname{Size}_{i, t-1}+\delta \operatorname{Dar}_{i, t-1}+\text { Year }_{t}+\varepsilon_{i, t}
$$

where $P_{i, t}$ is the performance in year t, and $P_{j, t}$ is the performance of industry j (based on the 33 industry classifications of the Tokyo Stock Exchange) which firm i belongs to in year t. Thus the dependent variable is the standardized performance ${ }^{23}$. It is highly relevant to use the standardized performance because the issue here is corporate efficiency which is independent of industry common factors. It could also reduce the reverse causality problem: the estimation might capture a stakeholder that bought or held onto a high performer's shares rather than signifying the large shareholder's promotion of firm efficiency. Because consolidated accounting data is available in our NLIR-Waseda database, the current value ROA on a consolidated basis and Tobin's q are used for the index of performance ${ }^{24}$.

The explanatory variable $S I Z E_{i, t}$ is the logarithm of total assets, $D A R_{i, t}$ is the leverage (interest-bearing debt / total assets) of firm i in year $t$, and Year $_{t}$ is a dummy variable which takes the value one in year $t$. These are included to control for factors affecting performance other than ownership structure.

Gov $_{i, t-1}$ is the governance structure of firm $\mathrm{i}$ in year $\mathrm{t}-1$. It includes the various shareholding ratios for domestic and foreign institutional investors and for the ratio of stable shareholders. To obtain a variable that represents foreign institutional investors more precisely, we calculate the share of foreign institutional investors, $F R G N$. This is done by eliminating foreign corporations and domestic pension funds via foreign countries from the shares held by foreign shareholders. STAB is the ratio of stable shareholders, which is then decomposed into the ratio of bank ownership $B K S H$ and that of non-bank ownership, NBKSH. Notice that the correlation between FRGN and STAB $(B K S H, N B S K H)$ is not very high. For instance, the correlation coefficient between $F R G N$ and

\footnotetext{
${ }^{22}$ Considering the effect of outliers on the estimation results for explanatory variables except dummy variables, all values deviating more than three standard deviations from sample means are replaced by sample means plus three standard deviations.

23 We also estimated the regression using (1) each of the row figures of the performance index, (2) the yearly changes of the industry-standardized performance as dependent variables. The results are unchanged.

24 Tobin's $q$ is strictly constructed in the NLIR and Waseda database by estimating current value of tangible assets, land, and securities, following the standard literature. See Miyajima et al. (2001).
} 
$B K S H$ is -0.17 . We also include the share of the main bank, $D_{-} M B S$, which takes the value 1 if main bank shareholding is nearly $5 \%$ (we take $4.9 \%$ as its threshold). We found that $26 \%$ of the entire sample of firms met this requirement.

Further, we added the dummy variable, $D \_P A R$, which is given the value of 1 when a corporation holds more than $15 \%$ of shares. This variable enables us to test the possibility that minority shareholders are exploited by controlling shareholders (parent companies). The ratio of such firms in our sample, namely, the ratio of "listed subsidiaries," is $26 \%$. Last, to capture the effect of managerial ownership, we introduced the dummy variable, $D_{-} D I R$, which is 1 if managerial ownership is higher than $5 \%^{25}$. The ratio of firms with the $D_{-} D I R$ equal to 1 is $13.1 \%$ in our sample.

In addition to the above variables for ownership structure, following Yermack (1996), we also added variables on the size of the board of directors, $B R N$, and the ratio of outsider directors, $O D R$, to the model. The expected sign of $B R N$ is negative because poor communication and decision-making are associated with large boards. All the explanatory variables are lagged by one period from the dependent variable to clarify the causality with corporate performance. Detailed definitions of the variables are in Appendix 3. The estimation results are presented in Table 8 on the full sample period and Table 9 on sub-periods.

\section{$==$ Table 8/9 about here $==$}

First, we observe that leverage has a positive effect on corporate performance. The result is consistent with the standard theoretical understanding of the disciplinary role of debt since Jensen (1986) and also coincides with recent studies by Horiuchi and Hanazaki (2001). According to Table 9, the effect of leverage is larger in the post-bubble and banking crisis periods than during the bubble period. This supports the notion that debt in general played an increasingly significant role for corporate governance in the 1990s.

Second, the ratio of outside directors, $O D R$, and the board size, $B R N$, have the expected signs but are not necessarily stable. While the sign of outside directors is positive and significant in both ROA and Q for the whole period, the results for sub-periods are not sufficiently significant in either ROA or Q (results are not shown). On the other hand, the size of boards is an insignificant factor in

25 We set this threshold following Morck, Schleifer and Vishney (1988). 
ROA over the whole period, whereas it shows high significance in sub-periods. From these results we see that the relationship between small boards and high performance that Yermack (1996) observed in U.S. firms is also the case for Japanese firms, particularly during the post-bubble period.

Third, managerial ownership levels exceeding a certain threshold may have negative effects on corporate performance ${ }^{26}$. Although the significance level is not sufficiently high, there is a possibility that managerial entrenchment is associated with high managerial ownership. The effect is clear in the bubble period and to a lesser extent in the post-bubble period. These results are consistent with the understanding that some family-owned firms tend to be over-invested.

Changing our focus to ownership structure, we observe that the ownership level of particular categories of stakeholders has strongly influenced corporate performance. First, shareholding by both domestic and foreign institutional investors has significantly positive effects. We generally expect that monitoring pressure for management increases if institutional investors hold shares above a certain level (Shleifer and Vishny 1986). Also, several authors have pointed out that since institutional investors have high monitoring abilities, they are effective at mitigating agency problems (McConnell and Servaes 1995, Nickell, Nicolitsas and Dryden 1997, etc). Consistent with these predictions, institutional investors likely contributed to performance enhancements by disciplining managers in the late 1990s. This effect is observed among not only foreign institutional investors but also domestic institutional investors.

\section{$=$ Table 9 about here $==$}

Second, firms that have parent companies perform significantly better. This is consistent with Kang and Shivdasani (1995) and Morck et al. (2000). In spite of the perceived conflict of interest between parent companies and minority shareholders, as far as the listed firms are concerned, serious problems regarding corporate governance are less likely in vertical corporate groups (keiretsu). In contrast, it appears that parent firms as block holders monitored their listed subsidiaries (related firms) effectively and improved their efficiencies.

Finally, as for stabilized shareholders, we find an inverse relationship between the shares held

\footnotetext{
${ }^{26}$ Morck at al (2000) reported a monotonous positive relationship between managerial ownership and Tobin's $q$, interpreting it to be the result of the alignment effect between managers' concerns and shareholders' interests. But we did not find such a relationship.
} 
by stable shareholders and performance in both ROA and Tobin's $\mathrm{q}^{27}$. In sub-sample estimation, the inverse relationship is clear in the bubble and post-bubble period. This is consistent with the idea that high stabilized shareholding can insulate managers from external pressures. On the other hand, the sign of main bank shareholding is negative and highly significant for the whole sample as well as both the post-bubble and banking crisis sub-periods. This result is also consistent with the entrenchment rather than monitoring view of the role of the main bank.

As we mentioned, both banks and non-banks were stable shareholders. Thus, the interesting task is to identify which of the two has a stronger effect on insulating managers from external pressures. Columns 3 and 4 of Table 9 decompose the stabilized shareholding ratio into the shares held by banks, $B K S H$, and the shares held by non-banks, $N B K S H$. Shares held by non-banks include shares held by non-financial institutions and insurance companies. Interestingly, in both ROA and Tobin's q estimation, the coefficient of $B K S H$ is highly significant, while that of the $N B K S H$ is negative but less significant. This suggests that the negative effect on performance came not from the shareholding among firms, but mainly from the shareholding by banks.

Furthermore, we observe in Table 9 that the coefficient of $B K S H$ is consistently negative and highly significant in all sub-sample periods. The magnitude of the effect is determined by multiplying the coefficient by one standard deviation of $B K S H:-0.269$ percent in the bubble period, -0.467 percent in the post-bubble period, and -0.317 percent in the banking crisis period respectively. This magnitude is almost the same as, or even higher than, that of foreign ownership. ${ }^{28}$ The largest negative effect was during the post-bubble period. Thus, it is unlikely that mutual shareholding among non-financial institutions promoted managerial discretion by shielding top management from market pressure. It is highly plausible that significant bank ownership or main bank shareholding negatively affected corporate governance, although we cannot disentangle whether this result came from the entrenchment effect or propping-up effect.

\section{$=$ Table 9 about here $==$}

The above estimations are not completely free from endogeneity problems. Even with standardized performance as a dependent variable and the appropriate lag and firm specific effects

27 The result holds if the independent variable is replaced with TFP (Miyajima et al. 2004).

28 The magnitude of FOR is 0.355 in the bubble period, 0.258 in the post-bubble period, and 0.310 in the banking crisis period. 
as independent variables, we cannot rule out that the estimation captures the reverse relationship (i.e., a stakeholder invested in high performers' shares rather than trying to keep firms efficient). Thus, further tests are necessary and the result is still tentative. These points notwithstanding, however, these results have several important implications.

First, the fact that institutional shareholding is consistently associated with high performance implies that it helps raise efficiency and is economically rational. There is no doubt that institutional shareholders played a significant monitoring role in Japanese firms by partly substituting for the (main) bank.

Second, the inverse relation between bank ownership and performance suggests that unwinding the cross-shareholding between banks and corporations clearly allows for efficiency gains. It is often pointed out that unwinding cross-shareholding may increase unnecessary pressures on management to think myopically (i.e. in terms of short-term rises in the price of their stock). However, as far as the cross-shareholding between banks and firms is concerned, the long-run positive effect of its unwinding on corporate governance in Japan is larger than any possible myopia effect in the 1990s.

Third, given that stable shareholding and high bank ownership stakes have had a consistently negative effect on corporate efficiency since the bubble period, the inefficiency associated with bank ownership per se was not necessary to cause the unwinding of cross-shareholding. The notion that less efficient institutions could not survive is not the case by the mid-1990s. There was inertia among firms and banks in their decision to hold stocks. As we explained in the previous section, it took an external shock such as the banking crisis to disrupt this inertia

Last, in contrast with previous research, mutual shareholding among non-financial institutions may not have a strong negative effect on corporate performance. Similarly, in contrast with a conflict of interest view of corporate shareholding, block shareholding of other non-financial institutions constantly played a significant role in corporate governance in Japanese firms. It is also unlikely that large numbers of block holders enabled the transfer of funds from minority shareholders' to the controlling shareholders as part of a "tunneling" scheme. While bank ownership of equity and loans, one of the salient features of the ownership structure in Japanese firms, has lost its raison d'être, other features such as the high share of block holding by corporations and cross-shareholding among firms have retained their economic rationale. 


\section{Conclusion and Perspectives}

This chapter investigated the causes and implications of the unwinding of cross-shareholding, which has been a major feature of the ownership structure of Japanese firms for the past few decades.

Why did the stable ownership structure begin to unwind in the late 1990s? The banking crisis was a crucial factor that directly led to the termination of many cross-shareholding arrangements between financial institutions and firms. After 1995, and especially since 1997, when the banking crisis came to the surface and grew acute, it became increasingly irrational for corporations to hold bank (financial institution) shares due to the high holding risk. Major commercial banks also began to sell off shares after the crisis mainly because of the need to secure funds to dispose of non-performing loans and to respond to BIS regulations. Because cross-shareholding is a mutual relationship, once one side decides to sell its partner's share, it is natural that the partner will respond and the unwinding will begin to accelerate.

However, it is worth noting that crucial changes were occurring prior to the banking crisis. First, large, highly profitable firms with outstanding credit ratings already depended on bonds and equities for their external financing. This eroded the simultaneous ownership of both debt and equity claims by Japanese banks. Second, foreign investors increased their stakes in these firms in the early 1990s. Subsequently, the share held by domestic institutional investors also rose. Institutional investors encouraged top managers to consider ROE and returns on investment. Third, it became evident that bank ownership was associated with low performance. This is possibly because higher bank ownership was associated with relaxed financial constraints, allowing firms to undertake more marginally acceptable investment opportunities.

These facts are extremely important because they explain the unevenness of the unwinding of cross-shareholding. As we emphasized in this chapter, the unwinding of cross-shareholding did not proceed uniformly among Japanese firms. The growing differentiation in the post-banking crisis period between firms that rapidly unwound cross-shareholding and firms that continued cross-shareholding was the result of rational choices by both corporations and banks.

Managers of profitable firms with easy access to capital markets and high foreign ownership prior to the banking crisis found little need to maintain financial relationships with banks. This made the unwinding of cross-shareholdings a rational way to earn a high market valuation. As 
Chapter 11 will explain, firms that actively reformed their boards of directors maintained high performance through capital market discipline. For low-profit firms with difficulty accessing capital markets and low foreign ownership in the early 1990s, - cross-shareholding, in particular between banks and firms, was maintained since managers needed strong relationships with banks for both financing and to stabilize ownership. As a result, management discipline was sacrificed and this led to poor performance. These are the firms that are both reluctant to reform their boards of directors and still maintain main-bank relationships as we saw in Chapter 1. They have fallen into a vicious circle of cross-shareholding and lax governance.

A key point is that firms that maintain cross-shareholding have little incentive to dissolve it. Managers of the firms with low profitability and strong bank relationships (in terms of both financing and shareholding) prior to the banking crisis do not have incentives to sell shares of banks whose profitability declined and holding risk went up. For banks, it is rational to continue holding onto corporate shares since selling the shares of firms with which they are connected sends negative signals to the market and can expose bad debts. If this circumstance continues, then the low market evaluations of these corporations are sustained and pressure from institutional investors or credit rating agencies has no effect. This mechanism explains how conventional J-type firms locked in to their traditional pattern of cross-shareholding in the late 1990s.

Against this backdrop, the simultaneous ownership of debt and equity became a systemic problem for Japanese firms in the late 1990s, and constituted an impediment to corporate reform. Locked-in firms have emerged as the most important targets of reform in Japan.

Moreover, the continuation of the above situation implies a degradation of banks' equity portfolios. The fact that the composition of borrowers deteriorated through the process of deregulation in the late 1980s has been pointed out by other studies (Miyajima and Arikawa 2001). The key result that has emerged from this chapter is that after 1997, when the banking crisis occurred, banks sold shares of firms with high growth opportunities (large Tobin's q) and held shares of firms with which they had main-bank relationships even as their holding risks rose.

\section{Perspectives on the future}

By examining the causes and effects of the unwinding of cross-shareholding, we can extract some perspectives on the future. 
We emphasized the vicious circle between bank ownership and low levels of governance, and the organizational lock-in of conventional J-type firms. However, this does not necessary imply the existence of a stable equilibrium. Policymakers have gradually recognized the vicious circle described above and taken various measures that have started to show some effect. The Banks' Shareholding Restriction Law, promulgated in September 2001, required banks to reduce their stock holdings up to the same amount of their equity (originally by September 2004, and with recent revisions, by September 2006). This provided a substantial impetus to sell off corporate shares. Both the Banks' Shareholdings Purchase Corporation (BSPC) and the Bank of Japan began to buy stock directly from city banks at market price with certain conditions in 2002. However, since the law only required a reduction in the total volume of shares held, and the Bank of Japan's purchases were limited to stock with credit ratings of BBB and higher, it is likely that banks may have held onto shares of firms with low profitability and high risk, and sold only equity with high liquidity.

In this context, the bank mergers may have a substantial effect on further steps to encourage the severing of the vicious circle. Given the current Antitrust Law that sets a ceiling on the holding of stock by financial institutions of up to $5 \%$, the merged banks were required to sell holding shares. Furthermore, the changing ownership structure among major city banks themselves may give them an incentive to sell shares of firms with low profitability. In the process of reconstructing banks, the shares held by institutional shareholders increased as cross-shareholding with corporations dissolved. This would make it difficult for them to hold onto low-profit, high-risk firms. Thus, one possible (and optimistic) scenario has the locked-in relationship between major banks and firms gradually dissolving.

What then can we expect to happen to the ownership structure in the future? Cross-shareholding between banks and firms will without a doubt decrease from previous levels, while institutional shareholders will increase their stakes. In particular, domestic institutional investors will increase their presence. However, the cross-shareholding among firms will not be dissolved on a large scale, since corporate ownership of shares has its own economic rationale. For instance, cross-shareholding arrangements help reduce moral hazard risks (opportunistic behaviors) among trading partners, thus facilitating transaction-specific investment (Flath 1993). In addition, there is no indication that it has played a negative role in corporate governance (corporate block 
holding has in fact played a positive role). Japanese firms now have the option of forming a holding company, which will also encourage corporate ownership of shares. Thus, the ownership structure of Japanese firms that was characterized by cross-shareholding among corporations and financial institutions will gradually change to a more market-based system but still retain some of the features of cross-shareholding arrangements, perhaps by combining cross-ownership by corporations and shareholding by institutional investors.

In this process, a decrease in stable shareholding is likely to increase the likelihood of hostile takeovers In fact, some have already occurred in the 2000s. The amendment to the Company Law slated for 2006 will make it possible for foreign firms to buy Japanese firms through exchanges of stock. This will certainly open the door wider to mergers and acquisitions. Accordingly, the real challenge that Japanese firms will face (or have been facing) is how to manage the hostile takeover threat. The key for policymakers is to design an institutional framework that utilizes the emerging market for corporate control on the one hand while providing firms with appropriate means to fend off unwanted suitors. 


\section{Appendices: Definition of Variables}

\section{Appendix 1. Corporation's Choice of Bank Shareholding}

\section{$X_{1}$ Variables representing the need to sell off shares}

D_ICR: Dummy variable is 1 if corporation i's interest coverage ratio [(operating profit + interest and dividends income)/ interest cost] is 1.5 or less.

$\boldsymbol{D} / \boldsymbol{E}$ : Corporation i's D/E ratio (interest-bearing debt/ equity capital).

$\boldsymbol{B S V / A}$ : The ratio of bank j's shares held by corporation i at market value in its total assets.

\section{$X_{2}$ Financial health}

D_FRD: Dummy variable is 1 if Moody's bank financial rating is D or below (all banks have received D or below since 1999, thus the dummy is 1 if $\mathrm{E}$ or below for this period), otherwise 0. Seven out of 14 banks received C or above ratings in 1995, six banks received C or above in 1997, and no banks received C and only three received D or above in 1999.

\section{$X_{3}$ Variables representing pressure from capital market}

D_CRB: Dummy variable takes value of 1 if corporation i's credit rating for long-term bonds is BB-BBB (if the corporation received ratings from multiple rating agencies, we choose the most conservative rating).

D_CRA: Dummy variable takes value of 1 if corporation i's credit rating for long-term bonds is A-AAA (if the corporation received ratings from multiple rating agencies, we choose the most conservative rating).

\section{$X_{4}$ Variable representing managerial entrenchment against the threat of takeover}

LEMV: Logarithm of corporation i's total market capitalization.

NOST: Ratio of shareholding by non-stable shareholders (the sum of shares held by individuals excluding board members, foreign and domestic institutional investors) if the corporation has cross-shareholding relationship with banks, and 0 otherwise.

\section{$X_{5}$ Variables representing the relationship between corporations and banks}

$\boldsymbol{B B R}$ : Corporation i's borrowing from bank $\mathrm{j}$ divided by total borrowing from private financial institutions.

$\boldsymbol{B H R}$ : Bank j's shareholding of corporation i divided by total issued shares of corporation i. 
$\boldsymbol{D} \_\boldsymbol{M B}$ : Dummy variable is 1 if bank $\mathrm{j}$ is a main bank of some corporation (this represents closeness to corporations in total financial transactions). The main bank is defined as a bank that is the top listed bank in the column of the business partner banks in "the Japan Company Handbook" of Toyo Keizai Inc.

The distribution of $\boldsymbol{B B R}$ (mean, standard deviation) is $(8.7 \%, 9.5 \%)$ in period I, $(9.4 \%, 10.1 \%)$ in period II, and $(12.3 \%, 12.8 \%)$ in period III. The distribution of $\boldsymbol{B H R}$ is $(1.7 \%, 1.8 \%)$ in period I, $(1.9 \%, 1.8 \%)$ in period II, and $(2.4 \%, 2.0 \%)$ in period III. The mean values of both variables are increasing due to the effect of bank restructurings.

\section{$X_{6}$ Dummy variables representing bank $\mathbf{j}$ 's sell off of corporation i's shares}

$\boldsymbol{B S L}$ : Dummy variable representing that bank j sold off corporation i's shares in the same year.

PBSL: Dummy variable representing that bank j sold off corporation i's shares in the previous year.

D_BM: Dummy variable to control for the effects of a bank merger, which is 1 if shares of separate banks in the beginning of the period become shares of the same bank by the end of the period.

D_YY: Dummy variable for year effects.

\section{Appendix 2. Bank's Choice of Shareholding}

\section{$Z_{1}$ Variables to control for bank j's investment behavior}

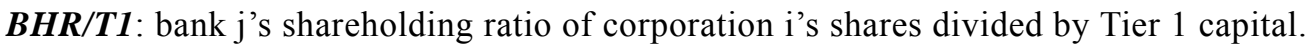

LEMV: Logarithm of corporation i's total market capitalization (This represents liquidity and ease of selling off).

\section{$Z_{2} \quad$ A variable representing pressure from capital market to banks}

D_FRD: Dummy variable is 1 if Moody's bank financial rating is D or below (all banks have received D or below since 1999, thus dummy is 1 if E or below for this period).

$Z_{3} \quad$ Variables representing corporation i's (investment target firm) risk (credit risk and volatility), and growth opportunities

D_ICR: Dummy variable is 1 if corporation i's interest coverage ratio [(operating profit + interest and dividends income)/ interest cost] is 1.5 or less.

D_AVQ: Dummy variable is 1 if corporation i's Tobin's q is 2 or more. 
$\boldsymbol{D} / \boldsymbol{E}$ : Corporation i's D/E ratio (interest-bearing debt/ equity capital).

SDRTN: Standard deviation of monthly return from corporation i's share in the past 36 months.

\section{$Z_{4}$ Variables representing the long-term relationship between banks and corporations}

$\boldsymbol{B B R}$ : Corporation i's borrowing from bank $\mathrm{j}$ divided by total borrowing from private financial institutions (this represents the degree of dependency on the liabilities side).

D_CSH: Dummy variable is 1 if corporation i holds bank j's shares (cross-shareholding) at the beginning of the period.

D_MB: Dummy variable is 1 if bank j is a main bank of some corporation.

\section{$Z_{5} \quad$ Variables representing corporation i's sale of bank j's shares}

CSL: Dummy variable indicating that corporation i sold off bank j's shares in the same year.

PCSL: Dummy variable indicating that corporation i sold off bank j's shares in the previous year.

\section{Appendix 3. Effect of Ownership on Corporate Performance}

\section{Dependent variables:}

$\boldsymbol{R O A}$ (return on assets): business profit/ total assets (average at the beginning and end of period).

Business profit $=$ operating profit + interest and dividend income

Total assets $=$ book value of total assets + unrealized capital gain (loss) from tangible fixed assets + unrealized capital gain (loss) from securities

$\boldsymbol{A V Q}$ : Tobin's q: value of the firm (end of period)/ total assets (end of period).

Value of the firm $=$ market value shareholder's equity + book value debt + minority equity

Total assets $=$ book value of total assets + unrealized capital gain (loss) from tangible fixed assets + unrealized capital gain (loss) from securities

\section{Independent variables:}

FRGN: Shareholding ratio of foreign institutional investors: shareholding ratio of foreigners shareholding ratio of foreign corporate block shareholders.

DINS: Shareholding ratio of domestic institutional investors: annuity trust + investment trust + total shareholding ratio of life insurance companies' special accounting.

$\boldsymbol{S T A B}$ : Ratio of stable shareholders: ratio of cross-shareholding + total shareholding ratio of banks and life insurance companies. 
ODR: Ratio of outside board members: number of outside board members/ number of board members.

BRN: Relative number of board members: number of board members/ logarithm of the number of employees.

D_DIR: Board member shareholding dummy: Dummy variable is 1 if shareholding ratio of board members is more than $5 \%$.

D_PAR: Domestic and foreign parent company dummy: Dummy variable is 1 if there is a related parent company (domestic or foreign non-financial corporation which has more than $15 \%$ shareholding ratio).

D_MBS: Main bank shareholding dummy. Dummy variable is 1 if main bank shareholding ratio is nearly $5 \%$ (we take $4.9 \%$ as its threshold). 


\section{References}

Abegglen, J. C. and G. Stalk Jr. 1985. Kaisha:Tthe Japanese Corporation. Charles E. Tuttle.

Aoki, M. 1988. Information, Incentives, and Bargaining in the Japanese Economy. Cambridge University Press.

Allen, F. and D. Gale. 2000. Comparing Financial Systems. MIT Press.

Aoki, M and H. Patrick, eds. 1994. The Japanese Main-bank System: Its Relevancy for Developing and Transforming Economies. Oxford: Oxford University Press.

Burkart, M., D. Gromb and F. Panunzi. 1997. 'Large Shareholders, Monitoring, and the Value of the Firm,' The Quarterly Journal of Economics, 112(3), pp.693-728.

Classens, S., S. Djankow, J. Fan and L. Lang. 1999. 'The Rationale for Groups: Evidence from East Asia,' Unpublished manuscript. The World Bank.

Flath, D. 1993. 'Shareholding in the Keiretsu: Japan's Financial Groups,' The Review of Economics and Statistics, 75(2), pp.249-257.

Horiuchi, A. and M. Hanazaki. 2000. 'Did the Main-bank Relationship Help Make Corporate Management Efficient?: Empirical Analysis of the Manufacturing Industry,' Keizai Keiei Kenkyu (Research Institute of Capital Formation, Development Bank of Japan), 21-1. (in Japanese).

Jensen, M. C. 1986. 'Agency Costs of Free Cash Flow, Corporate Finance, and Takeover,' American Economic Review, 76, pp.323-329.

Johnson, S., P. Boone, A. Breach and E. Friedman. 2000. 'Corporate Governance in the Asian Financial Crisis,' Journal of Financial Economics, 58(1), pp.141-86.

Kang, J. and A. Shivdasani (1995), 'Firm Performance, Corporate Governance, and Top Executive Turnover in Japan,' Journal of Financial Economics, 38(1), pp.29-58.

Kang, J. and R. Stultz, (1997), 'Why is There a Home Bias? An Analysis of Foreign Portfolio Equity Ownership in Japan,' Journal of Financial Economics, 46(1), pp.3-28.

La Porta, R., F. Lopez-de-Silanes, A. Shleifer and R. Vishny. 1998. 'Law and Finance,' Journal of Political Economy, 106(6), pp.1113-1155.

Lichtenberg, F. R. and G. M. Pushner. 1994. 'Ownership Structure and Corporate Performance in Japan,' Japan and World Economy, 6, pp.239-261.

McConnell, J. J. and H. Servaes. 1995. 'Equity Ownership and the Two Faces of Debt,' Journal of Financial Economics, 39(1), pp.131-157.

Miyajima, H. 1995). 'The Privatization of Ex-zaibatsu Holding Stocks and the Emergence of Bank-centered Corporate Groups,' M. Aoki, ed. Corporate Governance in Transitional Economy, The World Bank, 1995, pp.361-403.

Miyajima, H. and Y. Arikawa. 2000. 'Relational Banking and Debt Choice: Evidence from the Liberalization in Japan,' IFMP Discussion Paper Series, A00-07.

Miyajima, H. 2004. Microanalysis of the Development of the Japanese Economy: Corporate Governance and Industrial Policy. Yuhikaku. (in Japanese) 
Miyajima, H., Y. Arikawa and T. Saito. 2001. 'Japanese Corporate Governance and "Excess" Investment: Comparative Analysis of Oil Shocks and Bubble Years,' Financial Review (Policy Research Institute of MOF) 60. (in Japanese)

Miyajima, H., K. Nitta, T. Saito and Y. Omi. 2002. 'Governance Structure and Productivity of Japanese Firms in the 1990s: Did Transformation of Governance Structure Contribute to the Improvement of Managerial Efficiency?' Working Paper WFIS-02-001, Waseda University Institute of Financial Studies. (in Japanese)

Miyajima, H. and F. Kuroki. 2002. 'Quantitative Analysis of the Unwinding of Cross-shareholding by Japanese Firms,' Security Analysts Journal, 40(12), pp.30-46. (in Japanese)

Miyajima, H., K. Haramura and Y. Enami. 2003. 'Evolution of Ownership Structure in Postwar Japan: Formulation and Unwinding of Stable Shareholders,' Financial Review (Policy Research Institute of MOF) 68. (in Japanese)

Morck, R. A. Shleifer and R. Vishny. 1988. 'Management Ownership and Market Valuation: An Empirical Analysis,' Journal of Financial Economics, 20.

Morck, R., M. Nakamura and A. Shivdasani. 2000. 'Banks, Ownership Structure, and Firm Value in Japan,' The Journal of Business, 73(4), pp.539-567.

Morck, R. and B. Yeung. 2001. 'Japanese Economic Success and the Curious Characteristics of the Japanese Stock Market,' Paper presented at IMF-Hitotsubashi Conference. September.

Murase, A. 2001. 'Stock Investment Performance of Japanese Financial Institutions, Corporations, Individuals, and Foreign Investors,' Review of Monetary and Financial Studies 17. (in Japanese)

Nakatani, I. 1984. 'The Economic Role of Financial Corporate Groupings,' in Masahiko Aoki ed., The Economic Analysis of the Japanese Firm. Amsterdam, North-Holland.

Odagiri, H. 1992. Growth through Competition, Competition through Growth: Strategic Management and the Economy in Japan. Oxford University Press.

Okabe, M. 2002. Cross Shareholding in Japan: A New Unified Perspective of the Economic System. Edward Elgar Publishing.

Peek, J and E. Rosengren. 2001. 'Determinants of the Japan Premium: Actions Speak Louder than Words,' Journal of International Economics, 53, pp.283-305.

Porter, M. E. 1992. 'Capital Disadvantage: America's Failing Capital Investment System,' Harvard Business Review, 70, pp.65-82.

Porter, M. E. 1994. Capital Choices. Harvard University Press.

Prowse, S. 1990. 'Institutional Investment Patterns and Corporate Financial Behaviors in the United States and Japan,' Journal of Financial Economics, 27(1), pp. 43-66.

Sheard, P. 1994. 'Interlocking Shareholdings and Corporate Governance in Japan,' in M. Aoki and R. Dore, eds., The Japanese Firm: Sources of Competitive Strength. Oxford. Oxford University Press, pp .314-349.

Shleifer, A. and R. W. Vishny. 1986. 'Large Shareholders and Corporate Control,' Journal of Political Economy, 94(3), pp.461-488. 
Weinstein, D. and Y. Yafeh. 1998. "On the Costs of a Bank-centered Financial System: Evidence from the Changing Main-bank Relations in Japan," Journal of Finance, 53, pp.635-672.

Yermack, D. 1996. 'Higher Market Valuation of Companies with a Small Board Directors', Journal of Financial Economics, 40.

Yafeh Y. 2000. 'Corporate Governance in Japan: Past Performance and Future Prospects,' Oxford Review of Economic Policy, 16(2), pp.74-84.

Yafeh Y. and O. Yosha. 2003. 'Large Shareholders and Banks: Who Monitors and How?' Economic Journal, 113, 484, pp.128-146. 
Figure 1 Long-term trends in ownership structure of Japanese listed firms

$(\%)$

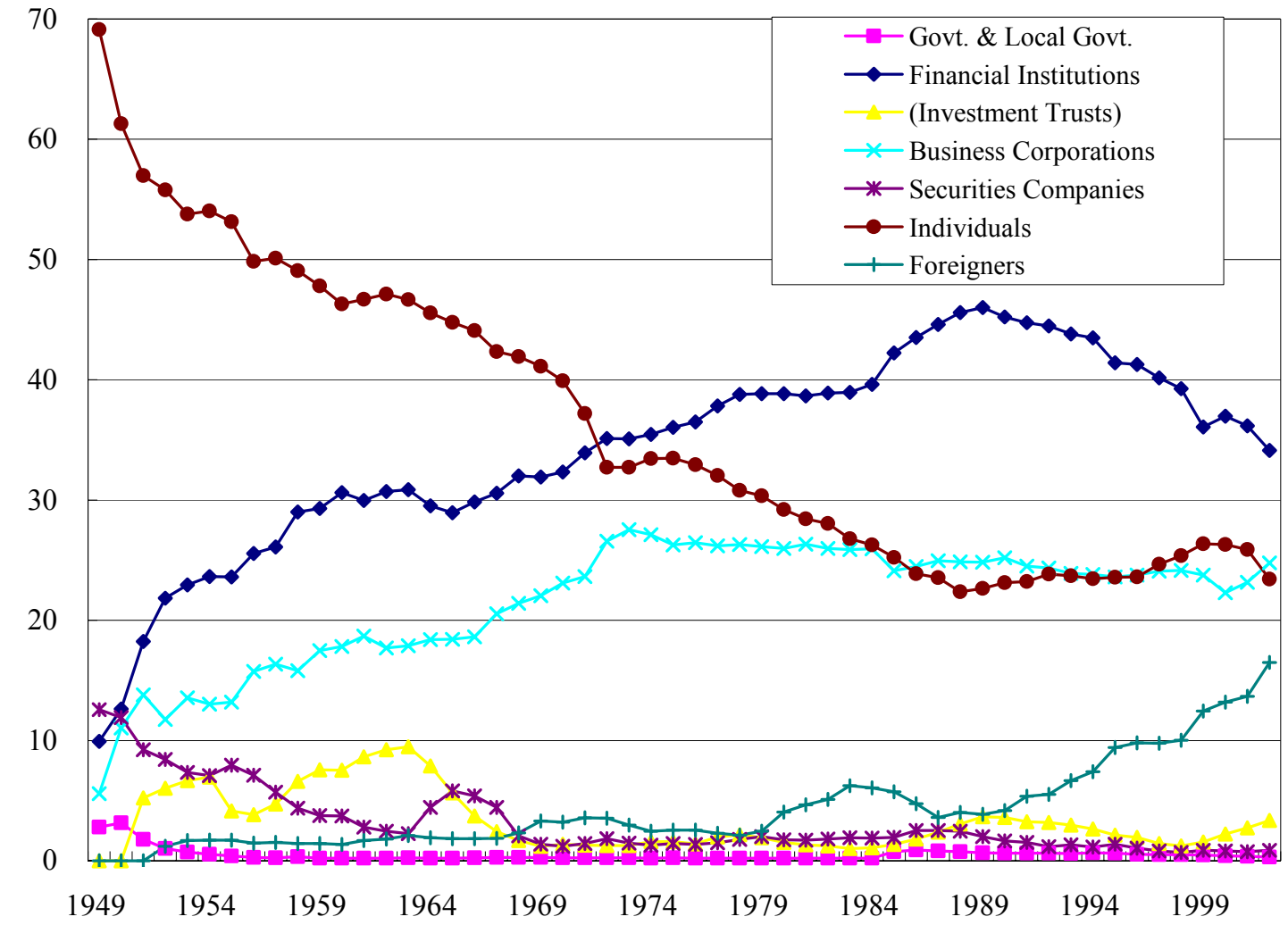

(source) 2002 Shareownership Survey: All domestic stock exchanges 
Figure 2 :Co-movement of Industry-specific Stock Price Indexes and Bank Stock Prices, 1995-2002

Stock Price Indices (1995 March $=100)$

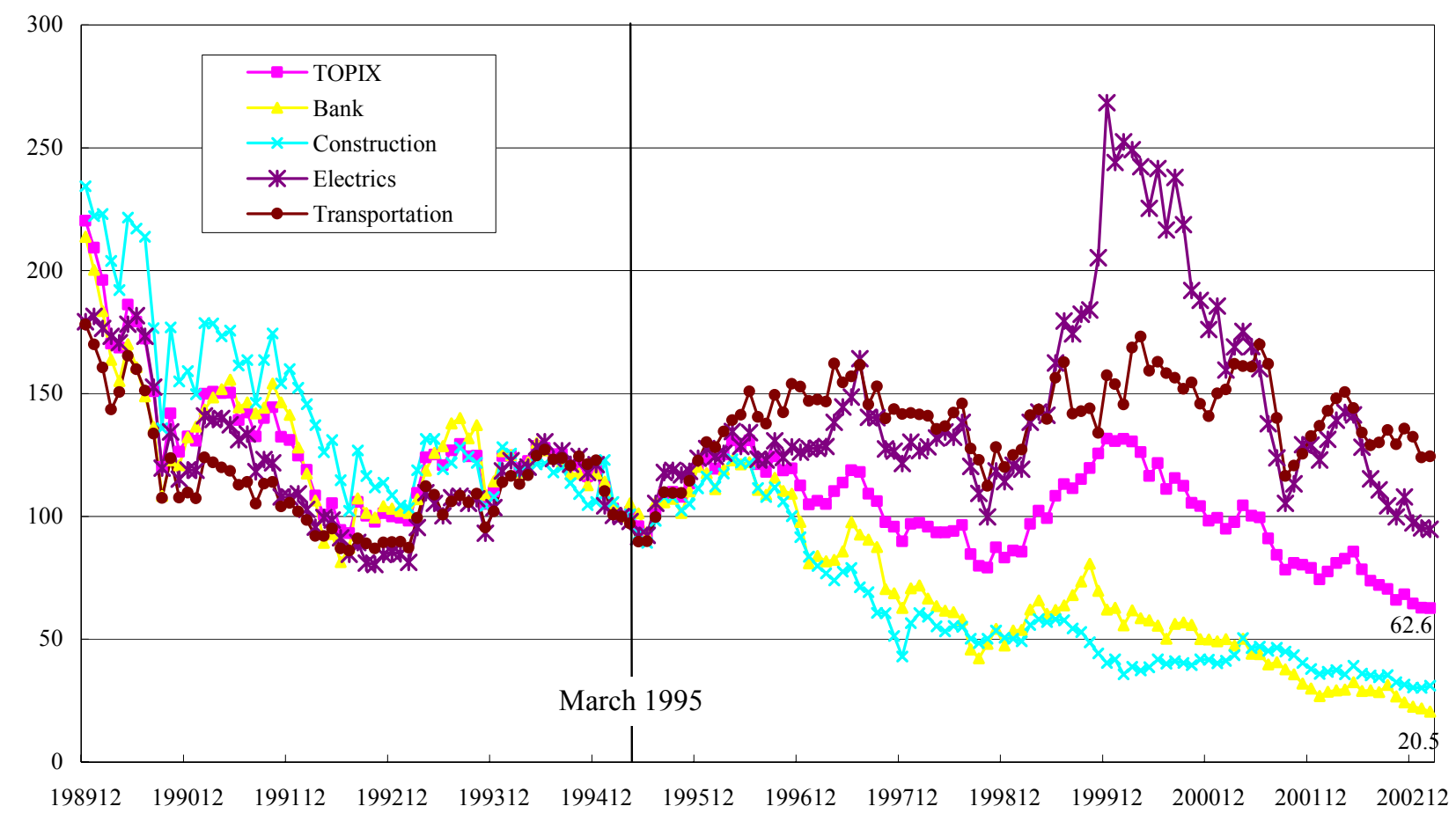

Note: Based on the Tokyo Stock Exchange industry-specific indices 
Figure 3 :Rate of Selling and Buying

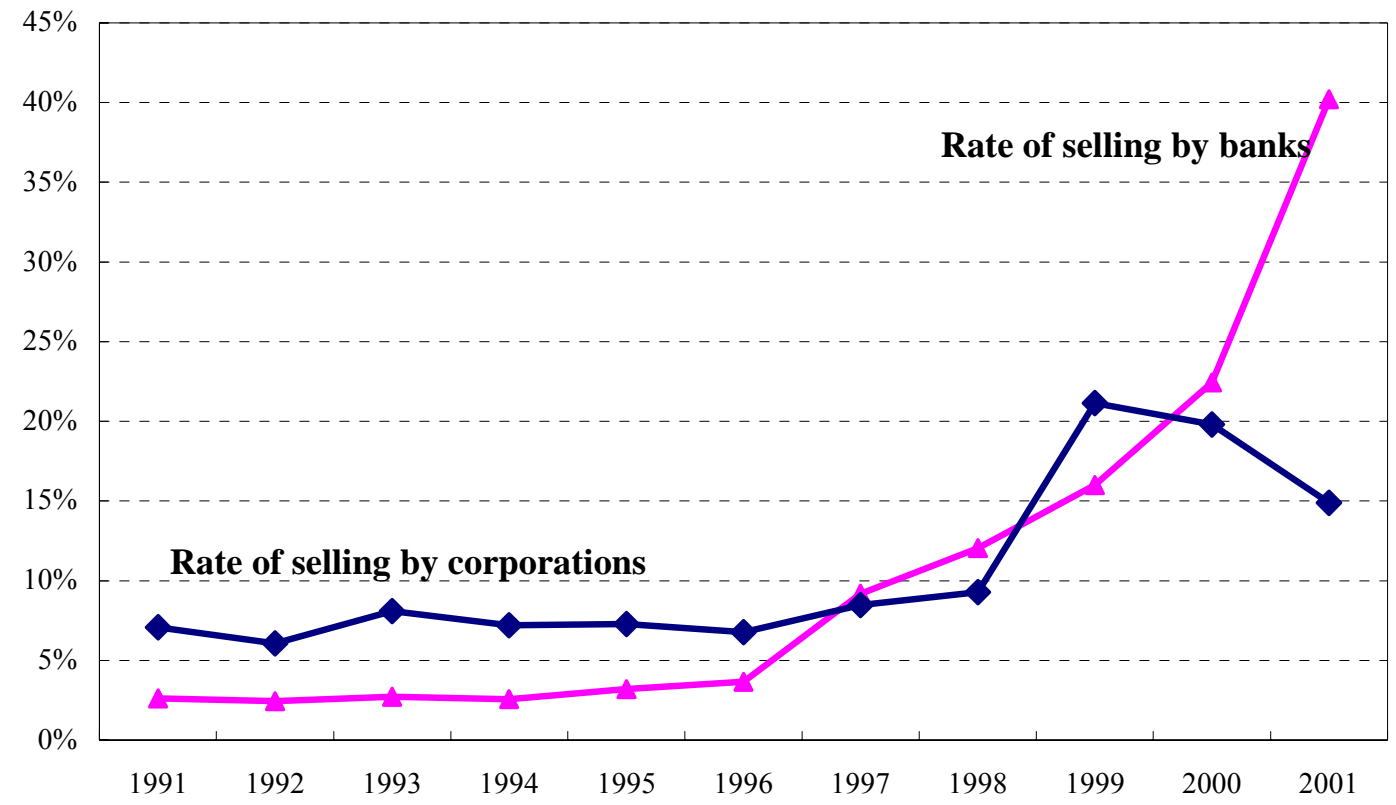

Note 1: Rate of selling by banks = number of corporate stocks sold by banks during a firm year

/ number of corporate stocks held at the beginning of the firm year

Note 2: Rate of selling by corporations $=$ number of bank stocks sold during a firm year

/ number of bank stocks held at the beginning of the firm year

Note 3: When it was not possible to determine the number of shares held at the end of period and whether the shares were sold or the shares were not disclosed, we did not count the case as an instance of selling. 
Stable shareholder ratio: percentage of market value of listed firms owned by stable shareholders (value of shares owned by stable shareholders/total firm market ve An aggregate of the ratio of shares held by banks, insurance firms, and non-financial firms. Source: NLI Research Institute.

\begin{tabular}{|c|c|c|c|c|c|c|c|c|c|c|}
\hline \multirow{3}{*}{$\begin{array}{l}\text { The end } \\
\text { of FY }\end{array}$} & \multirow{3}{*}{$\begin{array}{l}\text { No. of } \\
\text { Firms }\end{array}$} & \multirow{3}{*}{$\begin{array}{l}\text { Total Firm } \\
\text { Value } \\
\text { (Trillion yen) }\end{array}$} & \multirow{2}{*}{\multicolumn{2}{|c|}{$\begin{array}{c}\text { Stable Shareholder } \\
\text { Ratio }\end{array}$}} & \multirow{2}{*}{\multicolumn{2}{|c|}{ Banks }} & \multirow{2}{*}{\multicolumn{2}{|c|}{ Insurance Firms }} & \multirow{2}{*}{\multicolumn{2}{|c|}{ Non-Financial Firms }} \\
\hline & & & & & & & & & & \\
\hline & & & (\% of Total) & (change) & (\% of Total) & (change) & (\% of Total) & (change) & (\% of Total) & (change) \\
\hline 1987 & 1,924 & 433 & 45.8 & & 14.9 & & 16.4 & & 14.4 & \\
\hline 1988 & 1,975 & 517 & 45.7 & $\Delta 0.10$ & 15.6 & 0.70 & 16.6 & 0.20 & 13.3 & $\mathbf{\Delta} 1.10$ \\
\hline 1989 & 2,031 & 500 & 44.9 & $\Delta 0.80$ & 15.6 & 0.00 & 15.7 & $\Delta 0.90$ & 13.4 & 0.10 \\
\hline 1990 & 2,078 & 450 & 45.6 & 0.70 & 15.7 & 0.10 & 15.8 & 0.10 & 14.0 & 0.60 \\
\hline 1991 & 2,107 & 326 & 45.6 & 0.00 & 15.6 & $\Delta 0.10$ & 16.2 & 0.40 & 13.7 & $\Delta 0.30$ \\
\hline 1992 & 2,120 & 328 & 45.7 & 0.10 & 15.6 & 0.00 & 16.2 & 0.00 & 13.8 & 0.10 \\
\hline 1993 & 2,161 & 367 & 45.2 & $\Delta 0.50$ & 15.4 & $\Delta 0.20$ & 15.8 & $\Delta 0.40$ & 14.0 & 0.20 \\
\hline 1994 & 2,214 & 311 & 44.9 & $\Delta 0.30$ & 15.4 & 0.00 & 15.7 & $\Delta 0.10$ & 13.7 & $\Delta 0.30$ \\
\hline 1995 & 2,279 & 393 & 43.4 & $\Delta 1.50$ & 15.0 & $\Delta 0.40$ & 14.7 & $\mathbf{\Delta} 1.00$ & 13.5 & $\Delta 0.20$ \\
\hline 1996 & 2,341 & 335 & 42.1 & $\boldsymbol{\Delta} 1.30$ & 15.1 & 0.10 & 14.7 & 0.00 & 12.2 & $\mathbf{\Delta} 1.30$ \\
\hline 1997 & 2,389 & 308 & 40.5 & $\Delta 1.60$ & 14.8 & $\Delta 0.30$ & 14.1 & $\Delta 0.60$ & 11.6 & $\Delta 0.60$ \\
\hline 1998 & 2,433 & 331 & 39.9 & $\Delta 0.60$ & 13.7 & $\boldsymbol{\Delta} 1.10$ & 13.0 & $\boldsymbol{\Delta} 1.10$ & 13.2 & 1.60 \\
\hline 1999 & 2,487 & 463 & 37.9 & $\Delta 2.00$ & 11.3 & $\boldsymbol{\Delta} 2.40$ & 10.6 & $\boldsymbol{\Delta} 2.40$ & 15.9 & 2.70 \\
\hline 2000 & 2,602 & 368 & 33.0 & $\Delta 4.90$ & 9.8 & $\Delta 1.50$ & 10.9 & 0.30 & 12.3 & $\Delta 3.60$ \\
\hline 2001 & 2,668 & 313 & 30.2 & $\boldsymbol{\Delta} 2.80$ & 8.7 & $\Delta 1.10$ & 10.1 & $\Delta 0.80$ & 11.4 & $\Delta 0.90$ \\
\hline 2002 & 2,674 & 237 & 27.1 & $\Delta 3.10$ & 7.7 & $\Delta 1.00$ & 9.3 & $\Delta 0.80$ & 10.0 & $\Delta 1.40$ \\
\hline
\end{tabular}


Table 2 :The Ratio of Shareholding by Type of Shareholder

Sample consists of 931 non-financial firms listed on the First Section of the Tokyo Stock Exchange for the entire period from the end of 1990 to the end of 2000. The percentage of shares held by individuals excludes shares held by board Source: Based on financial statements of each firm, major shareholder data (Toyo Keizai Shinposha), etc

\begin{tabular}{|c|c|c|c|c|c|c|c|c|c|}
\hline \multirow[b]{2}{*}{ Year } & \multicolumn{3}{|c|}{$\begin{array}{c}\text { Percentage of Shares held by } \\
\text { Foreigners }\end{array}$} & \multicolumn{3}{|c|}{$\begin{array}{l}\text { Percentage of Shares held by } \\
\text { Individuals }\end{array}$} & \multicolumn{3}{|c|}{$\begin{array}{l}\text { Percentage of Shares held by } \\
\text { Corporations and Banks }\end{array}$} \\
\hline & 1990 & 1995 & 2000 & 1990 & 1995 & 2000 & 1990 & 1995 & 2000 \\
\hline Mean & 4.3 & 7.8 & 7.9 & 20.8 & 22.6 & 30.6 & 37.5 & 34.9 & 32.6 \\
\hline Std. Dev. & 5.8 & 8.0 & 10.1 & 8.1 & 9.7 & 14.3 & 13.2 & 13.0 & 14.4 \\
\hline Coef. of Variance & 1.37 & 1.02 & 1.27 & 0.39 & 0.43 & 0.47 & 0.35 & 0.37 & 0.44 \\
\hline Median & 2.4 & 5.7 & 3.3 & 19.6 & 21.5 & 30.3 & 35.8 & 32.9 & 30.6 \\
\hline First quartile & 1.1 & 1.8 & 1.2 & 14.9 & 15.2 & 18.9 & 27.7 & 25.0 & 21.7 \\
\hline Third quartile & 5.2 & 11.4 & 11.3 & 25.9 & 28.6 & 40.2 & 46.7 & 43.6 & 41.4 \\
\hline 3Q-1Q & 4.0 & 9.6 & 10.1 & 11.0 & 13.4 & 21.3 & 18.9 & 18.6 & 19.7 \\
\hline
\end{tabular}


Table 3 :Trading Volume of Stocks by Investor Category

Source: Tokyo Stock Exchange, Annual Report on Stock Statistics (Based on three markets --Tokyo, Osaka, Nagoya).

(Unit : One Million Shares)

\begin{tabular}{|c|c|c|c|c|c|c|c|c|c|c|c|}
\hline \multirow[b]{2}{*}{ Year } & \multirow{2}{*}{\multicolumn{3}{|c|}{ Net Purchases }} & \multicolumn{8}{|c|}{ Net Purchases } \\
\hline & & & & $\begin{array}{c}\text { Securities } \\
\text { Companies }\end{array}$ & Individuals & $\begin{array}{c}\text { Investment } \\
\text { Trusts }\end{array}$ & Foreigners & $\begin{array}{c}\text { Business } \\
\text { Companies }\end{array}$ & $\begin{array}{c}\text { Insurance } \\
\text { Companies }\end{array}$ & $\begin{array}{c}\text { LTCB, City } \\
\text { and } \\
\text { Regional } \\
\text { Banks }\end{array}$ & $\begin{array}{c}\text { Trust } \\
\text { Banks }\end{array}$ \\
\hline 1990 & 125,253 & 125,362 & 109 & 94 & 1,467 & 852 & $\mathbf{\Delta} 1,806$ & 780 & 118 & $\mathbf{A} 1,223$ & \\
\hline 1991 & 94,030 & 94,983 & 952 & A 164 & $\mathbf{\Delta} 2,159$ & $\mathbf{A} 1,324$ & 4,146 & $\Delta 1,593$ & 370 & 1,429 & \\
\hline 1992 & 71,913 & 72,467 & 554 & $\mathbf{\Delta} 103$ & 160 & 366 & 229 & $\mathbf{A} 1,002$ & $\mathbf{A} 172$ & 1,307 & \\
\hline 1993 & 89,154 & 89,860 & 706 & $\Delta 109$ & $\mathbf{\Delta} 1,025$ & A 581 & 1,298 & $\Delta 1,961$ & $\Delta 45$ & 3,060 & \\
\hline 1994 & 92,894 & 93,726 & 831 & A 149 & A 1,843 & $\mathbf{\Delta} 1,727$ & 4,969 & $\mathbf{\Delta} 2,062$ & $\mathbf{\Delta} 634$ & 1,739 & \\
\hline 1995 & 103,521 & 103,933 & 412 & 116 & 615 & $\mathbf{\Delta} 1,252$ & 3,357 & $\mathbf{A} 1,303$ & $\Delta 2,020$ & A 313 & \\
\hline 1996 & 108,919 & 109,517 & 599 & $\Delta 91$ & $\mathbf{\Delta} 1,101$ & $\Delta 1,021$ & 2,473 & $\mathbf{\Delta} 1,314$ & А 520 & 1,017 & 1,664 \\
\hline 1997 & 112,241 & 112,102 & A 139 & 410 & 4,398 & $\mathbf{\Delta} 1,580$ & $\mathbf{\Delta} 1,154$ & $\boldsymbol{\Delta} 152$ & $\mathbf{\Delta} 1,498$ & $\mathbf{\Delta} 1,382$ & 2,451 \\
\hline 1998 & 118,067 & 117,792 & $\Delta 275$ & 323 & 4,098 & А 518 & $\mathbf{\Delta} 2,092$ & $\mathbf{\Delta} 1,251$ & $\mathbf{\Delta} 1,849$ & $\boldsymbol{\Delta} 1,856$ & 2,854 \\
\hline 1999 & 150,259 & 149,877 & А 382 & 374 & 2,626 & А 390 & 7,229 & $\mathbf{\Delta} 2,280$ & $\mathbf{\Delta} 2,468$ & $\mathbf{\Delta} 2,415$ & A 1,491 \\
\hline 2000 & 167,397 & 167,370 & $\mathbf{\Delta} 27$ & 396 & 943 & 1,030 & $\mathbf{\Delta} 729$ & $\mathbf{\Delta} 1,828$ & $\boldsymbol{\Delta} 722$ & $\Delta 1,507$ & 933 \\
\hline 2001 & 184,767 & 185,179 & 412 & 198 & 1,338 & 607 & А 976 & $\mathbf{\Delta} 605$ & $\mathbf{\Delta} 1,432$ & $\Delta 1,496$ & 2,122 \\
\hline 2002 & 194,690 & 194,878 & 188 & 10 & 1,064 & $\mathbf{\Delta} 46$ & А 223 & 328 & $\mathbf{\Delta} 840$ & $\Delta 1,376$ & 1,530 \\
\hline
\end{tabular}




\section{Table 4 :Determinants of Foreign Shareholding in Ownership Structure (Cross Section)}

Sample firms are large listed firms in the First Section of Tokyo Stock Exchange, which have over 50 billion yen turnover. Financial institutions and public utilities are excluded. Dependent variable $\triangle F O R$ : difference in the shareholding ratio by foreigners in each five-year period. FOR is the share held by foreign shareholders, which excludes the share held by foreign corporations. $A V Q$ is calculated with the share reported in the survey of shareholders. Tobin's q for the estimation period is a five-year average. $D A R$ is the leverage: the sum of borrowing and bonds divided by the total assets. SIZE is the logarithm of total assets (market value). DIST is a dummy variable that is given the value of 1 if net profit (after-tax profit) becomes non-positive at any time in the estimation period. This table first appeared in Miyajima et al. (2003).

\begin{tabular}{|c|c|c|c|c|}
\hline \multirow[b]{2}{*}{ Variable } & \multicolumn{2}{|c|}{$1989-94$} & \multicolumn{2}{|c|}{$1994-99$} \\
\hline & $\begin{array}{r}\text { Est. Coef. } \\
\text { (t-stat.) } \\
\end{array}$ & $\begin{array}{r}\text { Est. Coef. } \\
\text { (t-stat.) }\end{array}$ & $\begin{array}{r}\text { Est. Coef. } \\
\text { (t-stat.) } \\
\end{array}$ & $\begin{array}{r}\text { Est. Coef. } \\
\text { (t-stat.) } \\
\end{array}$ \\
\hline$C$ & $\begin{array}{c}-22.388 \\
(-7.13)\end{array}$ & $\begin{array}{r}-22.446 \\
(-7.16) \\
\end{array}$ & $\begin{array}{r}-39.053 \\
(-9.60)\end{array}$ & $\begin{array}{r}-38.991 \\
(-9.60) \\
\end{array}$ \\
\hline FOR(-5) & $\begin{array}{l}-0.005 \\
(-0.17)\end{array}$ & $\begin{array}{l}-0.014 \\
(-0.46)\end{array}$ & $\begin{array}{l}-0.062 \\
(-1.60) \\
\end{array}$ & $\begin{array}{l}-0.072 \\
(-1.85)\end{array}$ \\
\hline$A V Q$ & $\begin{array}{l}2.181^{* * *} \\
(2.20)\end{array}$ & $\begin{array}{l}2.369^{* *} \\
(2.38)\end{array}$ & $\begin{array}{l}6.082^{* * *} \\
(5.86)\end{array}$ & $\begin{array}{l}6.202^{\text {*** }} \\
(5.97)\end{array}$ \\
\hline SIZE(-5) & $\begin{array}{l}1.786^{* * *} \\
(9.96)^{2}\end{array}$ & $\begin{array}{c}1.881 \\
(10.04)\end{array}$ & $\begin{array}{l}2.051^{* * *} \\
(8.40)\end{array}$ & $\begin{array}{l}2.145^{* * *} \\
(8.57)\end{array}$ \\
\hline$D A R(-5)$ & & $\begin{array}{l}-0.028 \\
(-1.72)\end{array}$ & & $\begin{array}{l}-0.031 \\
(-1.66)\end{array}$ \\
\hline$B O N(-5)$ & $\begin{array}{l}1.971^{* * *} \\
(3.26)\end{array}$ & $\begin{array}{l}1.618^{* *} \\
(2.54)\end{array}$ & $\begin{array}{l}0.729 \\
(0.93) \\
\end{array}$ & $\begin{array}{l}0.260 \\
(0.31) \\
\end{array}$ \\
\hline$\overline{D I S T}$ & $\begin{array}{l}-0.839 \\
(-1.96)\end{array}$ & $\begin{array}{l}-0.664 \\
(-1.51) \\
\end{array}$ & $\begin{array}{l}-2.178^{\text {*** }} \\
(-4.10)\end{array}$ & $\begin{array}{l}-1.980 \\
(-3.65)\end{array}$ \\
\hline Industry Dummy & YES & YES & YES & YES \\
\hline Adjusted $\mathrm{R}^{2}$ & 0.23 & 0.23 & 0.30 & 0.31 \\
\hline Number of Observations & 588 & 588 & 564 & 564 \\
\hline
\end{tabular}

${ }^{* * *}$ denotes significance at the $1 \%$ level; ${ }^{* *}$ denotes significance at the $5 \%$ level;

* denotes significance at the $10 \%$ level 


\section{Table 5 :Corporation's Decision to Sell Bank Shares}

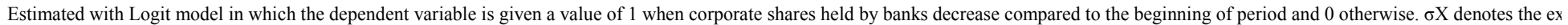
variable's standard deviation; $\mathrm{dP} / \mathrm{dX}$ denotes the marginal effect. Model 2 is limited to samples identifiable as instances of mutual shareholding between banks and corporations.

\begin{tabular}{|c|c|c|c|c|c|c|c|c|}
\hline & & & & Mo & el 1 & & Model 2 & Moc \\
\hline & 0.26087 & 0.13815096 & $\begin{array}{l}\text { Entire Period } \\
\text { FY95-FY2001 }\end{array}$ & $\begin{array}{c}\text { Period I } \\
\text { FY95-96 }\end{array}$ & $\begin{array}{l}\text { Period II } \\
\text { FY97-98 }\end{array}$ & $\begin{array}{c}\text { Period III } \\
\text { FY99-2001 }\end{array}$ & $\begin{array}{l}\text { Entire Period } \\
\text { FY95-FY2001 }\end{array}$ & $\begin{array}{l}\text { Entire } \\
\text { FY95-F }\end{array}$ \\
\hline & Variable & Definition & $\begin{array}{l}\text { Est. Coef. } \sigma_{\mathrm{X}} * \mathrm{dP} / \mathrm{dX} \\
\text { (-stat) }\end{array}$ & $\begin{array}{l}\text { Est. Coef. } \sigma_{\mathrm{X}} * \mathrm{dP} / \mathrm{dX} \\
\text { (-stat) }\end{array}$ & $\begin{array}{l}\begin{array}{l}\text { Est. Coef. } \sigma_{\mathrm{X}}{ }^{*} \mathrm{dP} / \mathrm{dX} \\
\text { (-stat) }\end{array} \\
\end{array}$ & $\begin{array}{l}\begin{array}{l}\text { Est. Coef. } \sigma_{\mathrm{X}}{ }^{*} \mathrm{dP} / \mathrm{dX} \\
\text { (-stat) }\end{array} \\
\end{array}$ & $\begin{array}{l}\begin{array}{l}\text { Est. Coef. } \sigma_{\mathrm{X}} * \mathrm{dP} / \mathrm{dX} \\
\text { (-stat) }\end{array} \\
\end{array}$ & $\begin{array}{c}\text { Est. Coef. } \\
\text { (-stat) }\end{array}$ \\
\hline & C & Constant & $\begin{array}{l}-3.641 \\
(-20.20)\end{array}$ & $\begin{array}{l}-6.314 \\
(-14.29)\end{array}$ & $\begin{array}{l}-4.910 \\
(-14.26)\end{array}$ & $\begin{array}{r}-2.925 \\
(-12.50)\end{array}{ }^{* * *}$ & $\begin{array}{c}-4.681 \\
(-19.38)\end{array}$ & $\begin{array}{r}-3.637 \\
(-20.16)\end{array}$ \\
\hline & D_ICR & 1 if $\mathrm{ICR}<1.5$ & $\begin{array}{ll}0.311 & 0.012 \\
(6.44)^{* * *} & \end{array}$ & 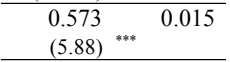 & $\begin{array}{ll}0.396 & 0.012 \\
(4.30))^{* * *} & \\
\end{array}$ & $\begin{array}{l}0.152 \\
(2.11)\end{array}$ & $\begin{array}{l}0.428 \\
(6.80)\end{array}$ & $\begin{array}{l}0.260 \\
(4.93) \\
\end{array}$ \\
\hline$X_{1}$ & $\overline{D / E}$ & $\mathrm{D} / \mathrm{E}$ ratio (interest-bearing debt/ owned capital) & $\begin{array}{c}0.214 \\
(17.97)^{* * *}\end{array}$ & 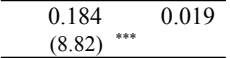 & $\begin{array}{l}0.133 \\
(5.82)^{* * *}\end{array}$ & $\begin{array}{c}0.142 \\
(13.01)^{* * *}\end{array}$ & $\begin{aligned} 0.249 \\
(14.81)^{* * *}\end{aligned}$ & $\begin{array}{r}0.215 \\
(18.00)\end{array}$ \\
\hline & $\overline{B S V / A}$ & $\begin{array}{l}\text { Bank shares at market value divided by total } \\
\text { assets }\end{array}$ & $\begin{array}{l}37.622 \\
(21.73)^{* * *}\end{array}$ & $\begin{aligned} & 19.658 \\
&(9.57)\end{aligned}{ }^{* * *}$ & $\begin{array}{l}37.455 \\
(11.27)^{* * *}\end{array}$ & $\begin{array}{ll}35.384 & 0.062 \\
(14.55)^{* * *} & \\
\end{array}$ & $\begin{array}{ll}30.150 & 0.039 \\
(18.87)^{* * *} & \\
\end{array}$ & $\begin{array}{l}37.080 \\
(21.23)\end{array}$ \\
\hline$X_{2}$ & $D_{-} F R D$ & $\begin{array}{l}\text { Dummy variable is } 1 \text { if bank finance rating is less than } \\
\mathrm{D} \text { (dummy is } 1 \text { if less than E since 1999) }\end{array}$ & $\begin{array}{l}0.387 \\
(9.80)^{* * *}\end{array}$ & $\begin{array}{l}0.210 \\
(2.59)^{* * *}\end{array}$ & $\begin{array}{l}0.421 \\
(5.58)^{* * *}\end{array}$ & 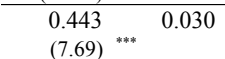 & 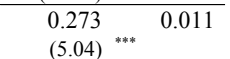 & $\begin{array}{r}0.446 \\
(10.44)\end{array}$ \\
\hline & $D_{-} C R B$ & $\begin{array}{l}\text { Dummy for rating (worst among four rating } \\
\text { companies') is BB-BBB }\end{array}$ & $\begin{array}{l}0.333 \\
(7.28)\end{array}$ & $\begin{array}{l}0.415 \\
(4.19)^{* * *}\end{array}$ & $\begin{array}{l}0.324 \\
(3.44)^{* * *}\end{array}$ & $\begin{array}{l}0.331 \\
(5.32)\end{array}{ }^{* * *}$ & $\begin{array}{l}0.371 \\
(6.09)^{* * *}\end{array}$ & $\begin{array}{l}0.334 \\
(7.29)\end{array}$ \\
\hline $\boldsymbol{X}$ & $\overline{D \_C R A}$ & $\begin{array}{l}\text { Dummy for rating (worst among four rating } \\
\text { companies) is A-AAA }\end{array}$ & $\begin{array}{l}0.101 \\
(1.76)\end{array}$ & $\begin{array}{l}0.043 \\
(0.34) \\
\end{array}$ & $\begin{array}{l}0.184 \\
(1.69)\end{array} *$ & $\begin{array}{l}0.016 \\
(0.20) \\
\end{array}$ & $\begin{array}{l}0.083 \\
(1.05) \\
\end{array}$ & $\begin{array}{l}0.103 \\
(1.79)\end{array}$ \\
\hline & $L E M V$ & $\begin{array}{l}\text { Logarithm of a corporation's aggregate market } \\
\text { value of shares }\end{array}$ & $\begin{array}{ll}0.143 & 0.019 \\
(9.39)\end{array}$ & 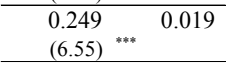 & $\begin{array}{l}0.209 \\
(6.88)^{* * *}\end{array}$ & $\begin{array}{ll}0.087 & 0.020 \\
(4.38)^{* * *} & \\
\end{array}$ & $\begin{array}{l}0.151 \\
(7.33)^{* * *}\end{array}$ & $\begin{array}{l}0.142 \\
(9.33)\end{array}$ \\
\hline $\boldsymbol{X}_{4}$ & $\overline{N O S T}$ & $\begin{array}{l}\text { if the corporation has cross-shareholding relationship } \\
\text { with hanks }\end{array}$ & $\begin{array}{ll}-0.007 & -0.010 \\
(-4.22)\end{array}$ & $\begin{array}{ll}-0.008 & -0.007 \\
(-2.13)\end{array}$ & $\begin{array}{ll}0.004 & 0.004 \\
(1.04) & \\
\end{array}$ & $\begin{array}{ll}-0.010 & -0.023 \\
(-4.64)^{* * *} & \end{array}$ & & $\begin{array}{l}-0.007 \\
(-4.27)\end{array}$ \\
\hline & $B B R$ & $\begin{array}{l}\text { A corporation's borrowing from the bank } \\
\text { divided by total borrowing from private financial }\end{array}$ & 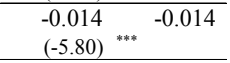 & $\begin{array}{l}-0.005 \\
(-0.95) \\
\end{array}$ & $\begin{array}{ll}-0.025 & -0.019 \\
(-4.30) & \\
\end{array}$ & $\begin{array}{ll}-0.012 & -0.022 \\
(-4.16) & \end{array}$ & 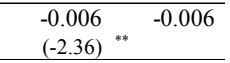 & $\begin{array}{l}-0.014 \\
(-5.89) \\
\end{array}$ \\
\hline$X_{5}$ & $\overline{B H R}$ & The bank's shareholding ratio & $\begin{array}{cc}-0.192 & -0.034 \\
(-11.06)\end{array}$ & $\begin{array}{l}-0.057 \\
(-1.51) \\
\end{array}$ & $\begin{array}{ll}-0.343 & -0.047 \\
(-8.42) & \\
\end{array}{ }^{* * *}$ & 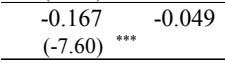 & 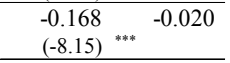 & $\begin{array}{r}-0.191 \\
(-10.96) \\
\end{array}$ \\
\hline & $\overline{D \_} M B$ & Dummy for main bank relationship & $\begin{array}{ll}0.111 \\
(1.81)\end{array} * 0.004$ & $\begin{array}{l}0.186 \\
(1.37)\end{array}$ & $\begin{array}{ll}0.347 \\
(2.47)\end{array}{ }^{* *} \quad 0.010$ & $\begin{array}{l}-0.008 \\
(-0.10)\end{array}$ & $\begin{array}{l}0.158 \\
(2.38)\end{array}$ & $\begin{array}{l}0.234 \\
(2.82)\end{array}$ \\
\hline $\boldsymbol{X}$ & $B S L$ & $\begin{array}{l}\text { Dummy for a bank's selling of corporate shares } \\
\text { in the same year }\end{array}$ & & & & & $\begin{array}{r}1.277 \\
(20.65)\end{array}$ & \\
\hline $\boldsymbol{A}_{6}$ & $\overline{P B S L}$ & $\begin{array}{l}\text { Dummy for a bank's selling of corporate shares } \\
\text { in the previous year }\end{array}$ & & & & & $\begin{array}{l}0.203 \\
(2.48)\end{array}$ & \\
\hline$A B$ & $M B I C R$ & Main bank interaction term (D_ICR) & & & & & & $\begin{array}{l}0.284 \\
(2.54) \\
\end{array}$ \\
\hline & $\overline{M B F R D}$ & Main bank interaction term (D_MDD) & & & & & & $\begin{array}{r}-0.342 \\
(-3.57)\end{array}$ \\
\hline & $D \_B M$ & Dummy for multiple bank merger & $\begin{array}{ll}0.398 & 0.006 \\
(4.11)^{* * *} & \end{array}$ & $\begin{array}{ll}0.621 \\
(2.98)\end{array} * 0.006$ & & $\begin{array}{ll}0.322 & \\
(2.91)^{* * * *} & 0.011\end{array}$ & $\begin{array}{l}0.246 \\
(2.19)\end{array}{ }^{* *}$ & $\begin{array}{l}0.426 \\
(4.38)\end{array}$ \\
\hline & $D Y Y$ & Year dummy & YES & YES & YES & YES & YES & $\mathrm{YI}$ \\
\hline & & Number of Observations & 31,700 & 11,163 & 10,029 & 10,508 & 20,947 & $31,^{\prime}$ \\
\hline & & Number of Selling Cases & 3,657 & 785 & 877 & 1,995 & 2,074 & 3,6 \\
\hline & & Rate of Selling & $11.5 \%$ & $7.0 \%$ & $8.7 \%$ & $19.0 \%$ & $9.9 \%$ & 11. \\
\hline & & Log Likelihood & $-10,269$ & $-2,658$ & $-2,777$ & $-4,794$ & $-5,886$ & -10 \\
\hline
\end{tabular}

${ }^{* * * *}$ denotes significance at the $1 \%$ level; ${ }^{* * *}$ denotes significance at the $5 \%$ level; ${ }^{*}$ denotes significance at the $10 \%$ level 


\section{Table 6 :Model of Banks' Decision to Sell Corporate Shares}

Estimated with a Logit model in which the dependent variable takes the value of 1 when corporate shares held by banks decrease compared to the beginning of the period and 0 otherwise. $\sigma \mathrm{X}$ denotes th explanatory variable's standard deviation; $\mathrm{dP} / \mathrm{dX}$ denotes marginal effects. Model 5 is limited to samples identified as cases of mutual shareholding between banks and corporatations.

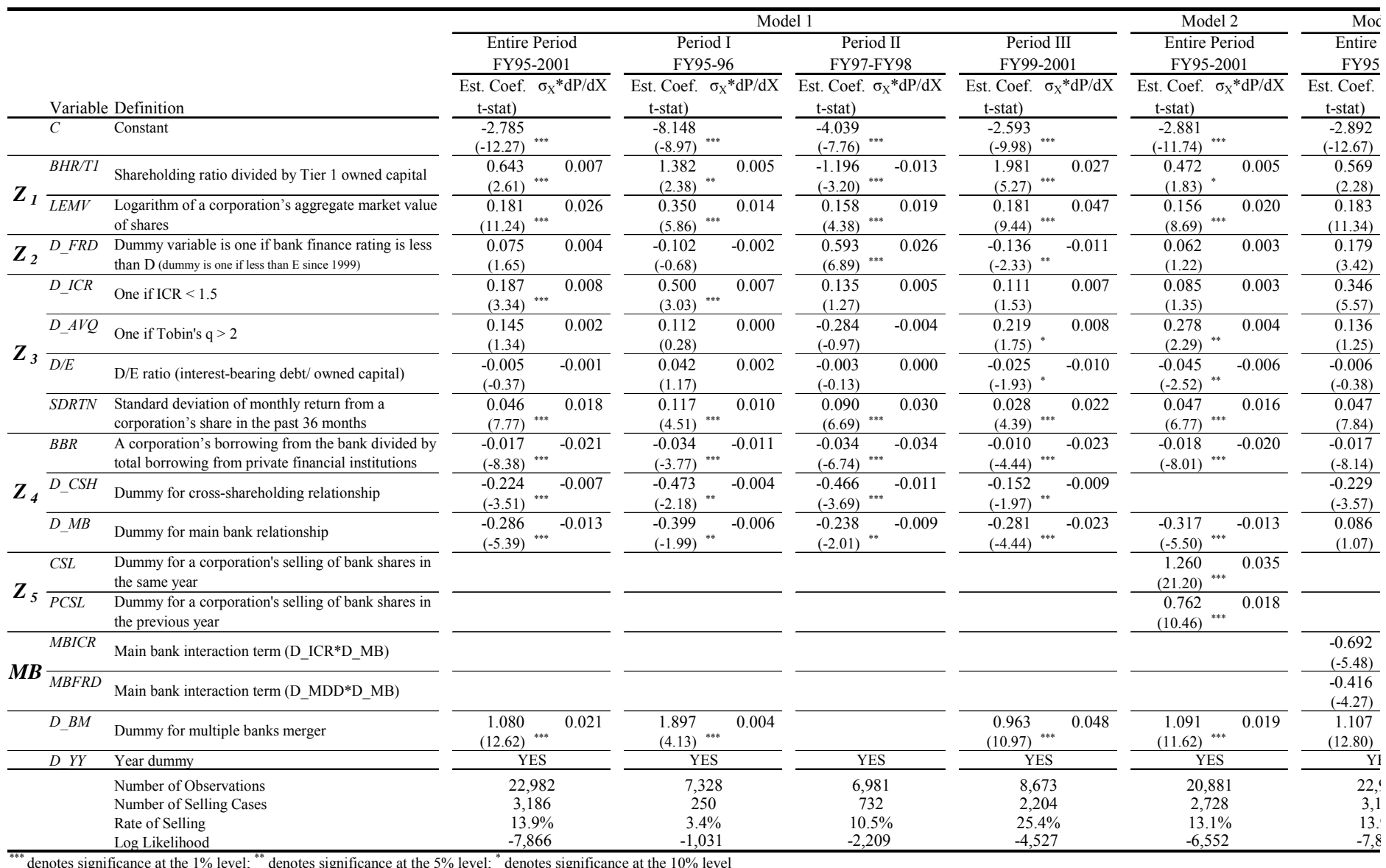




\section{Table7 :Model of Corporation's Decision to Sell Bank Shares}

Estimated with a Logit model in which the dependent variable takes the value of 1 when corporate shares held by banks decrease compared to the beginning of period and 0 otherwise. $\sigma \mathrm{X}$ denotes the explanatory variable's standard deviation; $\mathrm{dP} / \mathrm{dX}$ denotes marginal effects. Model 2 is limited to samples identified as cases of mutual shareholding between banks and corporatations. X1$\mathrm{X} 5$ in panel 1 and Z1-Z4 in panel 2 are not reported.

\section{Panel A :The impact of bank selling on corporate selling}

\begin{tabular}{|c|c|c|c|c|}
\hline \multirow{2}{*}{\multicolumn{2}{|c|}{ Variable Definition }} & $\begin{array}{l}\text { Period I } \\
\text { FY95-96) }\end{array}$ & $\begin{array}{c}\text { Period II } \\
\text { FY97-FY98) }\end{array}$ & $\begin{array}{l}\text { Period III } \\
\text { FY99-2001) }\end{array}$ \\
\hline & & $\begin{array}{l}\text { Est. Coef. } \sigma_{\mathrm{X}} * \mathrm{dP} / \mathrm{dX} \\
\text { (-stat) }\end{array}$ & $\begin{array}{l}\text { Est. Coef. } \sigma_{\mathrm{X}} * \mathrm{dP} / \mathrm{dX} \\
\text { (-stat) }\end{array}$ & $\begin{array}{l}\text { Est. Coef. } \sigma_{\mathrm{X}} * \mathrm{dP} / \mathrm{dX} \\
\text { (-stat) }\end{array}$ \\
\hline$X^{E}$ & $\begin{array}{c}\text { BSL Dummy for Bank Selling } \\
\text { \$ame Year) }\end{array}$ & 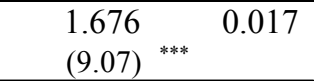 & $\begin{array}{r}2.011 \\
(15.77)\end{array}$ & $\begin{array}{r}0.976 \\
(12.98)\end{array}{ }^{* * *}$ \\
\hline 6 & $\begin{array}{l}\text { Dummy for Bank Selling } \\
\text { Previous Year) }\end{array}$ & $\begin{array}{l}0.044 \\
(0.15) \\
\end{array}$ & $\begin{array}{l}-0.097 \\
(-0.47)\end{array}$ & $\begin{array}{l}0.254 \\
(2.72)^{* * *}\end{array}$ \\
\hline
\end{tabular}

Panel B The impact of corporate selling on bank selling

\begin{tabular}{|c|c|c|c|c|}
\hline & & $\begin{array}{l}\text { Period I } \\
\text { FY95-96) }\end{array}$ & $\begin{array}{c}\text { Period II } \\
\text { FY97-FY98) }\end{array}$ & $\begin{array}{l}\text { Period III } \\
\text { FY99-01) }\end{array}$ \\
\hline & Variable Definition & $\begin{array}{l}\text { Est. Coef. } \sigma_{\mathrm{X}} * \mathrm{dP} / \mathrm{dX} \\
\text { (-stat) }\end{array}$ & $\begin{array}{l}\text { Est. Coef. } \sigma_{\mathrm{X}} * \mathrm{dP} / \mathrm{dX} \\
\text { (-stat) }\end{array}$ & $\begin{array}{l}\text { Est. Coef. } \sigma_{\mathrm{X}} * \mathrm{dP} / \mathrm{dX} \\
\text { (-stat) }\end{array}$ \\
\hline 7. & $\begin{array}{cc}C S L & \begin{array}{l}\text { Dummy for Corporate Selling } \\
\text { \$ame Year) }\end{array} \\
\end{array}$ & $\begin{array}{ll}1.580 & 0.012 \\
(8.55) & * * * \\
\end{array}$ & $\begin{array}{c}1.874 \\
(15.37)^{* * *}\end{array}$ & $\begin{array}{c}1.028 \\
(14.11)^{* * *}\end{array}$ \\
\hline$L_{5}$ & $\begin{array}{l}\text { Dummy for Corporate Selling } \\
\text { Previous Year) }\end{array}$ & $\begin{array}{l}0.289 \\
(1.29)\end{array}$ & $\begin{array}{ll}0.987 \\
(6.27)\end{array}{ }^{* * *}$ & $\begin{array}{l}0.748 \\
(8.31)^{* * *}\end{array}$ \\
\hline
\end{tabular}

${ }^{* * *}$ denotes significance at the $1 \%$ level; ${ }^{* *}$ denotes significance at the $5 \%$ level; ${ }^{*}$ denotes significance at the $10 \%$ level 
Table 8 :Estimation Results of the Effect of Cross-shareholding on Firm Performance (1985-2002)

Sample firms are non-financial firms listed in the three markets (excluding firms with less than one billion yen in owned capital or firms which have been listed less than three years). The estimation period is FY 1985 to 2002. ROA (return on assets) is the operating profit divided by current total assets (average at the beginning and end of the period), where total assets is the sum of book value total asset, unrealized capital gain (loss) from tangible fixed assets, and unrealized capital gain (loss) from securities. Q is Tobin's q: the value of the firm/ total assets (end of period), where the value of the firm is the sum of market value of equity, book value debt and minority equity. For more detail on definitions and methods of calculation, see Appendix 3.

\begin{tabular}{|c|c|c|c|c|c|}
\hline & & $\begin{array}{c}\text { Consolidataed } \\
\text { ROA } \\
\end{array}$ & Tobin's Q & $\begin{array}{l}\text { Consolidataed } \\
\text { ROA } \\
\end{array}$ & Tobin's Q \\
\hline Variable & Definition & $\begin{array}{r}\text { Est. Coef. } \\
\text { (t-stat.) } \\
\end{array}$ & $\begin{array}{r}\text { Est. Coef. } \\
\text { (t-stat.) }\end{array}$ & $\begin{array}{l}\text { Est. Coef. } \\
\text { (t-stat.) } \\
\end{array}$ & $\begin{array}{r}\text { Est. Coef. } \\
\text { (t-stat.) }\end{array}$ \\
\hline$\overline{S I Z E}$ & $\begin{array}{l}\text { Logarithm of total assets } \\
\text { (replacement value of assets) }\end{array}$ & $\begin{array}{r}-1.332 \\
(-16.21)\end{array}$ & $\begin{array}{r}-0.148 \\
(-14.65)\end{array}$ & $\begin{array}{l}-1.318 \\
(-16.05)\end{array}$ & $\begin{array}{r}-0.147 \\
(-14.50)\end{array}$ \\
\hline$D A R$ & $\begin{array}{l}\text { Leverage } \\
\text { (interest-bearing debt / total assets) }\end{array}$ & $\begin{array}{l}2.173^{* * *} \\
(9.21)\end{array}$ & $\begin{array}{l}0.477^{* * *} \\
(16.38)\end{array}$ & $\begin{array}{l}2.181^{* * *} \\
(9.24)\end{array}$ & $\begin{array}{l}0.478^{* * *} \\
(16.41)^{-}\end{array}$ \\
\hline FRGN & $\begin{array}{l}\text { Shareholding ratio of foreign } \\
\text { institutional investors }\end{array}$ & $\begin{array}{l}0.071^{* * *} \\
(15.15)^{*}\end{array}$ & $\begin{array}{l}0.013^{* * *} \\
(22.69)\end{array}$ & $\begin{array}{l}0.069^{* * *} \\
(14.73)^{*}\end{array}$ & $\begin{array}{l}0.013^{* * *} \\
(22.29)\end{array}$ \\
\hline DINS & $\begin{array}{l}\text { Shareholding ratio of domestic } \\
\text { institutional investors }\end{array}$ & $\begin{array}{l}0.093^{* * *} \\
(13.83)^{-}\end{array}$ & $\begin{array}{l}0.008^{* * *} \\
(10.24)^{4}\end{array}$ & $\begin{array}{l}0.090^{* * *} \\
(13.39)^{*}\end{array}$ & $\begin{array}{l}0.008^{* * *} \\
(9.86)\end{array}$ \\
\hline$S T A B$ & $\begin{array}{l}\text { Shareholding ratio of stable } \\
\text { shareholders }\end{array}$ & $\begin{array}{l}-0.007^{* * *} \\
(-2.74)^{4}\end{array}$ & $\begin{array}{l}-0.001^{* * *} \\
(-2.98)\end{array}$ & & \\
\hline$B K S H$ & Ratio of bank stable ownership & & & $\begin{array}{l}-0.044^{* * *} \\
(-4.60)\end{array}$ & $\begin{array}{l}-0.005^{* * *} \\
(-4.15)\end{array}$ \\
\hline$N B K S H$ & Ratio of non-bank stable ownership & & & $\begin{array}{l}-0.004 \\
(-1.48)\end{array}$ & $\begin{array}{l}-0.001 \\
(-1.84)\end{array}$ \\
\hline$O D R$ & Ratio of outside board members & $\begin{array}{l}0.634^{* * *} \\
(2.80)^{4}\end{array}$ & $\begin{array}{l}0.116^{* * *} \\
(4.15)^{-1}\end{array}$ & $\begin{array}{l}0.616^{* * *} \\
(2.72)\end{array}$ & $\begin{array}{l}0.114^{* * *} \\
(4.08)^{*}\end{array}$ \\
\hline$B R N$ & Relative number of board members & $\begin{array}{l}-0.033 \\
(-0.72)\end{array}$ & $\begin{array}{l}-0.025^{* * *} \\
(-4.35)\end{array}$ & $\begin{array}{l}-0.027 \\
(-0.59)\end{array}$ & $\begin{array}{l}-0.024^{* * *} \\
(-4.24)^{*}\end{array}$ \\
\hline$D \_D I R$ & Board member shareholding dummy & $\begin{array}{l}-0.1499^{*} \\
(-1.77)\end{array}$ & $\begin{array}{l}-0.023^{* *} \\
(-2.25)\end{array}$ & $\begin{array}{l}-0.145^{*} \\
(-1.72)\end{array}$ & $\begin{array}{l}-0.023^{* *} \\
(-2.20)\end{array}$ \\
\hline$D \_P A R$ & Parent company dummy & $\begin{array}{l}0.859^{* * *} \\
(7.04)\end{array}$ & $\begin{array}{l}0.080^{* * *} \\
(5.34)\end{array}$ & $\begin{array}{l}0.792^{* * *} \\
(6.43)^{*}\end{array}$ & $\begin{array}{l}0.073^{* * *} \\
(4.82)\end{array}$ \\
\hline$D_{-} M B S$ & Main bank shareholding dummy & $\begin{array}{l}-0.191^{* * *} \\
(-3.64)\end{array}$ & $\begin{array}{l}-0.026^{* * *} \\
(-3.99)\end{array}$ & $\begin{array}{l}-0.156^{* * *} \\
(-2.94)\end{array}$ & $\begin{array}{l}-0.022^{* * *} \\
(-3.37)^{*}\end{array}$ \\
\hline$D Y Y$ & Year dummy & YES & YES & YES & YES \\
\hline $\begin{array}{l}\text { Number of } \\
\text { Number of } \\
\text { Adjusted } \mathrm{F}\end{array}$ & $\begin{array}{l}\text { ervations } \\
\text { S }\end{array}$ & $\begin{array}{c}18,196 \\
1,305 \\
0.55\end{array}$ & $\begin{array}{c}18,196 \\
1,305 \\
0.50\end{array}$ & $\begin{array}{c}18,196 \\
1,305 \\
0.55\end{array}$ & $\begin{array}{c}18,196 \\
1,305 \\
0.50\end{array}$ \\
\hline
\end{tabular}

${ }^{* * *}$ denotes significance at the $1 \%$ level; ${ }^{* *}$ denotes significance at the $5 \%$ level;

* denotes significance at the $10 \%$ level 


\section{Table 9 Performance and Corporate Governance}

Sample firms are non-financial firms listed in the three markets (excluding firms with less than one billion yen in owned capital or firms which have been listed less than three years). The estimation period is FY 1985 to 2002. The dependent variable is ROA (return on assets) which is the operating profit divided by current total assets (average at the beginning and end of period), where total assets is the sum of book value of total assets, unrealized capital gain (loss) from tangible fixed assets, and unrealized capital gain (loss) from securities. For more details on definitions and methods of calculation, see Appendix 3.

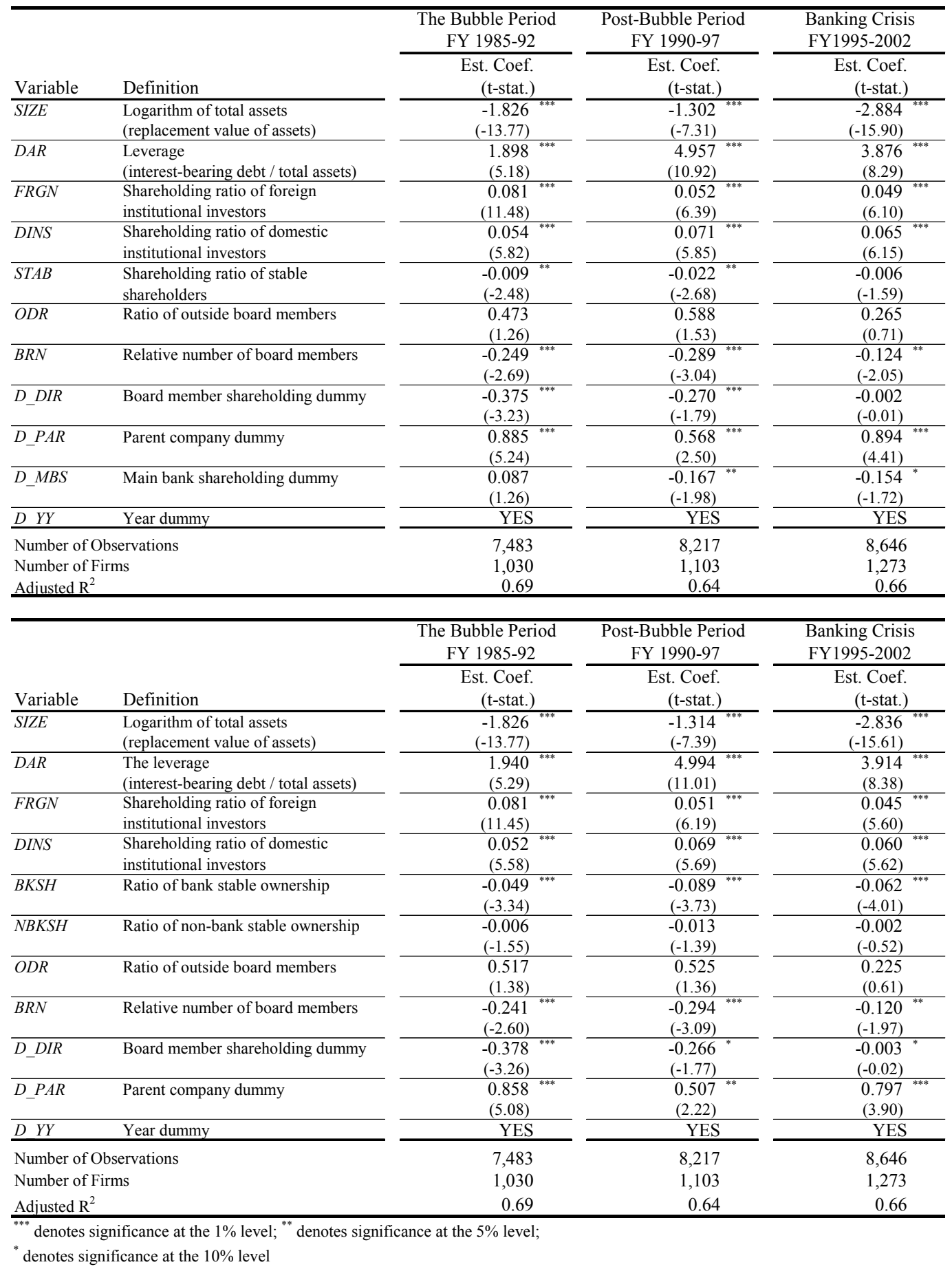

